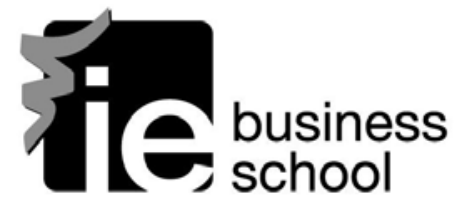

\section{REGULATION, INNOVATION AND PRODUCTIVITY}
IE Business School Working Paper
DE8-130-I
$15 / 07 / 2010$

\section{Francisco Marcos}

\section{Professor of Law, IE Law School} francisco.marcos@ie.edu

\author{
Juan Santaló \\ Professor of Strategy, IE Business School \\ juan.santalo@ie.edu
}

\begin{abstract}
This paper estimates the average effect of regulatory intensity and administrative redtape on productivity and innovation. For this purpose we exploit the exogenous variation of the decentralization process that has taken place in Spain during the last three decades. Using objective proxies for legislative and regulatory activity such as the number of pages and number of new norms published in the regional legislative reporters we find a strong negative impact of regulatory intensity on regional innovation and productivity. This negative effect of regional regulation is not only statistically significant but also of large economic importance and can explain the absence of productivity growth of Spain in the last decades. Finally, we provide evidence that regulatory intensity has affected the size distribution of establishment reducing its skewness and therefore affecting asymmetrically more those establishments that are more likely to innovate.
\end{abstract}

KEYWORDS: regulation, regulatory burden, decentralization, self-governing communities, regions, federalism, economic development, innovation, productivity, Spain

JEL CODES: D24, H73, H77, K20, 031, 047, 052, R50

ACKNOWLEDGEMENTS: A prior version of this paper, under the title "Decentralization, Regulatory Burden and Economic Development in Spain" was presented at the $24^{\text {th }}$ Annual Conference of the European Association of Law and Economics, celebrated at Copenhagen Business School in September 2007. The criticisms, comments and suggestions by the attendants to those meetings are hereby gratefully acknowledged. The authors are thankful for the financial support of the European Network for Better regulation and Spanish Ministry of Education's research grant \#SEJ2007-67582-C02-01.

Copyright (C) 2010 by Francisco Marcos professor at IE Law School and Juan Santaló Professor at IE Business School.

This working paper is distributed for purposes of comment and discussion only. It may not be reproduced without permission of the copyright holders. Copies of working papers are available from the authors. Printed at IE Business School, Madrid, Spain. Please, do not reproduce or circulate without permission. 


\section{INTRODUCTION.}

There are persistent differences in the rates of growth and economic development among countries. This difference is noticeable not only between developed and underdeveloped economies but also within the set of arguably developed countries like those belonging to the OECD. Distinct legal and regulatory frameworks are the usual suspects to explain this heterogeneity in economic growth since they are more or less adequate to promote investment, risk-taking and the innovation activities that are directly linked to the creation of economic value. As a result, a rich empirical literature has investigated the link between legal and regulatory heterogeneity and economic outcomes. However all this literature faces a common challenge that is prevalent in any empirical research that relates to the daunting task of properly telling apart causal links from statistical correlations. Moreover, it suffers from subjectivity biases in the construction of proxies for regulation and regulatory intensity. In this paper we exploit the quasi-natural experiment that constitutes the decentralization of the State in Spain, moving from a unified legal and regulatory framework in the middle of the 1980s to a quasi federal state composed by seventeen distinct legal regional entities in the beginnings of the $21^{\text {st }}$ century. The Spanish decentralization offers a exogenous variation in regional legislation both cross section and across time because regional political empowerment has followed separate time paths that have been driven by both historical reasons and the distinct political equilibriums that have occurred at the national and regional level during this period. In that setting we have built an unbiased index of regulatory intensity, which objectively measures variations in regional adoption of rules and legislation.

Complying with general regulations and administrative redtape is a costly burden that may affect the competitiveness and overall efficiency of the economy. The main purpose of this paper is to estimate the effect of these legal compliance costs on economic development, looking at regional variations. As explained above, Spain provides a suitable scenario to test some of the main implications of the abovementioned thesis of considering regulation and compliance as costs for businesses. The decentralization of legislative and regulatory powers from the Central Government to the Self Governing Communities (Comunidades Autónomas), SGCs, or hereinafter for simplicity referred as regions, -which began in the early 1980s and has been progressively developed until these days- has generated a substantial variety of situations that may turn to be useful in empirically evaluating the effect of the exercise of the legislative and regulatory powers by the regions on their economic development and business activities. In this paper we focus on estimating the effect of "red tape" on productivity and 
innovation of Spanish regions. For this purpose we construct a unique dataset that contains neutral measures of regulatory intensity at the regional level, such as the number of regional norms and number of regional pages of regulation in the legislative reporters, and we estimate its effect on regional total factor productivity and regional innovation. We find that regulatory intensity is associated to lower productivity and innovation. These effects are not only statistically significant but also of economic significance. Our estimates show that an increase of $100 \%$ in the number of local norms is associated with a decrease of $79-81 \%$ in the number of regional patents and a lower Total Factor Productivity (TFP) growth rate of around $3.5 \%$. This is a significant decrease since the Spanish TFP growth rate during the period has in fact a negative growth of $-0.15 \%$.

We also explore empirically the existence of two potential links between regulatory intensity and diminished productivity and innovation. We are unable to find any generic effect of regulatory intensity on product market competition measured by number of regional business establishments. However we find a negative association between regulatory intensity and the skewness of the size distribution of business establishments. More particularly we uncover that regulatory intensity is associated to a lower proportion of employees working for business establishments with 200 employees or more. This finding is consistent with a world in which regulatory intensity affects more the largest companies. This asymmetric effect could explain the negative effect of regulation on productivity and innovation since Giori et al. (2007) report that around $70 \%$ of the innovations in Europe are accounted by companies with 250 employees or more.

Overall, we contribute to the literature that investigates the economic effects of regulation in four different manners. First, we make use of a quasi experiment provided by the peculiarities of the Spanish legal framework that allows us to alleviate traditional endogeneity concerns when studying the link between regulation and economic outcomes. Second we have constructed a novel dataset of regulatory intensity variables (number of pages of regional legislative reporters and number of regional norms adopted) and shown its negative effect on productivity and innovation. This opens the door for future research to use similar regulatory variables in other international contexts. Third, the strong negative effects of regulatory intensity we report in this paper contribute to the literature that systematically finds a negative effect of regulatory burden on efficiency and productivity (Hsieh \& Klenow 2009; Restuccia \& Rogerson 2008). Finally, we provide evidence that the main channel through which regulation affects 
innovation and productivity is not necessarily by impairing product market competition but rather through its asymmetric negative effect on larger companies.

The rest of the paper is structured as follows. Section 2 describes the existing literature on the topic of study and related issues. Section 3 sets the analytical framework of why we can expect an impact of regulation on productivity and innovation; section 4 describes our data and variable construction; section 5 runs preliminary test to assess the external validity of our proxies of regulatory intensity. sections 6 and 7 display our main results, while section 8 runs robustness tests. Section 9 explores the empirical plausibility of two potential causes to explain the link between regulation and productivity: product market competition and asymmetric distortions in the allocation of resources. Section 10 concludes.

\section{RELATED LITERATURE.}

There is a rich literature that looks from different perspectives at how diverse institutional features impact on macroeconomics (Glaeser et al. 2004). Regulation is undoubtedly a key aspect of any institutional framework, and many works have sought to measure the economic effects of regulation. Indeed, there is a large body of empirical research studying regulation and its impact on economic growth and productivity. Several anecdotic references and commentaries have warned about the additional burden and compliance costs that the increase of rules and regulation introduce to business firms (Friedman 2004; Gattuso 2004). Lately some of these warnings have been specifically made in the Spanish context (Rosell 2006; Balmaseda 2004, 2005).

In the U.S. context, Goff (1996) looks at the effects of regulation (based on an Effective Regulatory Index constructed around quantity of regulation) on measures of economic performance to find large and strong negative effects of increases of the regulatory measures in GDP and unemployment. Christainsen \& Haveman (1981) report a significant impact of federal regulation in U.S. manufacturing productivity in the seventies. Similarly, Gray (1987) founds Occupational Safety and Health (OSH) and environmental protection regulation contributed greatly to the productivity slowdown in the U.S. manufacturing industry in the seventies. Introducing an environmental regulatory measure that captured also the extent of regulation enforcement, Gollop \& Roberts (1983) estimated a substantial drop in the productivity of electric power industry after the 1970 amendments to the Clean Air Act. Interestingly, Dufour et al. (1998) report that while OSH and environmental regulation had a negative impact in TPF of 
the Quebec manufacturing sector in the second half of the eighties, mandatory prevention programs and fines for infractions of OSH rules had a positive impact on TPF growth.

More recently, Dawson (2007) time-series study shows that U.S. federal regulation, measured by page-count of the Code of Federal Regulation (CFR), have had a strong negative impact $(0.24 \%$ in the overall period studied: 1949-1999) on economic performance measured as private business output, hours of labor services and private capital services; however, his attempt to analyze the impact of individual subjects of regulation (measured by each of the titles of the CFR) gave disparate results (the regulation in some areas having a negative impact whilst positive in others). Moreover, Dawson \& Seater (2007) find that U.S. federal regulation has a statistically and economically significant effect on aggregate output and total factor productivity, however the sign and magnitude of those effects have changed over time, occasionally regulation has even altered the mix of inputs through which output is produced.

Regulation impact on economic growth and business productivity has also been considered and compared cross-country, illustrating the negative effects over-regulation may have in growth and productivity. However, any transnational or comparative analysis of the issue faces problems related to different institutional frameworks in each country and legal system, which makes the analysis more difficult, and the comparisons futile (Siems 2005). National idiosyncrasy may make optimal for a country what it is not so in another one, and so forth. Moreover, countries are different in the economic and social backgrounds, and this may render numerical comparisons useless (i.e., domestic reality, which is richer than mere legal rules, explains better the economic success of a country compared with its neighbors).

Notwithstanding these difficulties, there are several studies that have analyzed and compared the economic impact of regulation cross-country. Indeed, Nicoletti \& Scarpetta (2003) show that changes in product market regulation in 18 OECD countries (measured by 3 qualitative indicators of regulation) from 1984-1998 affect overall productivity and that product regulation reduces multi-level productivity growth through the creation of larger barriers to entry. Using a similar dataset (different rough measures of product regulation for non-manufacturing industries in OECD countries, 1975-1998), Alesina et al. (2005) find robust evidence that tight regulation of product markets has a large negative effect on investment (deregulation increasing total investment). In the model constructed by Blanchard \& Giavazzi (2003) product market regulation creates rents and, thus, product market deregulation decreases rents, increasing competition, lowering prices and lowering unemployment (but raising real wages). Afterwards, 
due to the diminution in rents, incentives for workers to appropriate a proportion of these rents are reduced, facilitating labor market regulation.

On the other hand, based on the World Bank's dataset on business regulations Djankov, McLiesh \& Ramalho (2006) conclude that countries scoring better on that database have grown faster from 1993 to 2002 (measured by GDP). Using the World Bank's World Development Index (WDI) of government effectiveness and regulatory quality variables as a measure of regulation, Jajilian, Kirkpatrick \& Parker (2007) find a large and strong impact on growth. Using the regulation measure of the Fraser Institute's Index of Economic Freedom in 123 countries from 1970 to 1999, Gørgens, Paldman \& Wurth (2003) find out that heavily regulated countries grow about 2 or $3 \%$ less than liberal ones (no effect is found in moderate or low regulated countries).

Finally, Loyaza et al. (2004) made an empirical analysis of macroeconomic impact of regulation based on seventy-six countries in the 1990s. Building an overall regulation index (composed of entry regulation index, index of labor regulation, index of fiscal burden, index of trade barriers, index of financial markets regulation, index of contract enforcement and index of bankruptcy regulation) and they also taking into account institutional country features which may be relevant in looking at the economic impact of regulation, they conclude that heavier regulatory burden reduces growth (in terms of per capita GDP) and increases volatility, although the effects are smaller the stronger the quality of the country's institutional framework.

Overall, all these studies find a significant and negative effect of regulation on economic growth and productivity. However, such studies face two major difficulties: The first one consist in the difficulty in objectively measuring regulation itself. Any work on this area needs to deal first with designing tools to measure the extent and scope of regulation in the economy. As a result many regulatory indicators suffer from potential subjectivity bias, as they part from assumptions and valuations with weak independent grounding that may introduce biases or ideological prejudices as it happens with all the works above that use ad-hoc index of regulation like the indexes computed by the OCDE or the World Bank. The second difficulty lies in isolating the effects of legal rules on economic indicators from other confounding factors. Once a neutral measuring technique has been developed, it is only possible to estimate whether it has deleterious effect on economic activity as long as the characteristics of a dataset allows the use of econometric procedures that alleviate the concerns that we are really estimating the effect of regulation on economic activity, rather than the effect of other confounding factors. For 
example, Dawson (2007) and Dawson \& Seater (2007) studies suffer this second type of problem. Since they use time series variation to identify the effect of regulation, it is impossible to discern whether the estimated negative effects are indeed driven by regulation or by other contemporaneous factor that occurred at the same period of time.

However, the Spanish context provides an exceptional quasi natural experiment that allows us to circumvent the two difficulties faced by any study of the impact of regulation on productivity or on any other economic indicator. The beginning of decentralization in 1978 and its evolution from a unified regulatory system to a decentralized state in the subsequent times provide a first-rate framework for developing a numerical comparison of rules adopted and economic performance. Free from the reins of the Central Government, Spanish regions have adopted different models and options in the exercise of their powers. The recent history and evolution of the Spanish race towards a decentralized State provides a unique setting for analyzing regulation and its impact on the economic development of Spanish regions. The transfer of competencies to regions has given them powers to legislate or regulate many questions that were formerly governed by the central State. Over the years, Spanish regions have acquired relevance and powers that were previously non-existent and the rate of empowerment has differed across regions and across time in a path driven by the Spanish political equilibrium both at the national level and at the regional level (see Appendix A for data on evolution on powers transferred from the State to the regions). However their regional regulatory strategies have differed not only in the areas that they have regulated but also in the intensity with which regions have exercised their powers. We have developed an objective regional regulatory index that measures across time variations in regulatory intensity per region looking at the number of pages published in the regional legislative reporter and the number of norms adopted in each of the 17 Spanish regions, adjusted to the progressive transfer of powers in different areas from State to the regions (Marcos, Santaló \& Sánchez Graells 2010). Indeed, two previous studies have tried to measure the impact of regional regulation on regional productivity in Spain (Gual et al. 2006; Zárate \& Vallés 2010), but they suffer from some inconsistency in the construction of their regulatory indicators and, moreover they do not make full use of the exogenous variation provided by the different evolution of the levels of empowerment of the Spanish region in the process of decentralization of the Spanish state.

In the empirical section below we examine the extent in which regulatory intensity provokes less productivity and innovation but before we turn to the theoretical reasons why we should expect regulatory intensity to affect both productivity and innovation. 


\section{ANALYTICAL FRAMEWORK: THE EFFECT OF REGULATION ON INNOVATION}

\section{AND PRODUCTIVITY.}

The literature has identified two ways under which regulation can influence innovation strategies and firm productivity. First, regulation intensity can affect the nature of competition in the market place. For instance regulation could lift entry barriers (Nicoletti \& Scarpetta, 2003) and hence it could affect the number of competitors in any given industry. Alternatively regulation could simply restrict price competition (Nicoletti 2001; Nicoletti et al. 2001). Regardless of the particular regulatory driver, these changes in the competitive environment affect productivity because a strong impact has been found of market competition on the incentives of firms to invest in innovation activities. Nickell (1996) reports a positive impact of product market competition and productivity while Aghion et al. (2005) find that the linkage between competition and innovation follows an inverted $U$ curve relationship. This means that an enhanced product competition increases firm innovation/productivity when the initial levels of market competition are low and it decreases innovation investments when the initial levels of competition are high. Similarly Alesina et al. (2005) model theoretically and show empirical evidence in favor of a strong negative effect of regulation on investment through its effect on enhanced entry barriers.

An additional channel through which regulation could affect productivity is by distorting the optimal allocation of resources. Restuccia \& Rogerson (2008) show that policies which create heterogeneity in the prices faced by individual producers can lead to sizeable decreases in output and measured total factor productivity (TFP) in the range of 30 to $50 \%$. Hsieh \& Klenow (2009) use micro data on manufacturing establishments to quantify the potential extent of misallocation of resources in China and India compared to the U.S. They calculate that when capital and labor are hypothetically reallocated to equalize marginal products to the extent observed in the U.S., TFP could increase $30-50 \%$ in China and 40-60\% in India.

Additionally, red tape affects the time and resources that the top management team has to employ dealing with regulatory issues and requirements. Managerial time and resources are limited and the more time managers devote to adapt or circumvent to regulatory changes the less time they have to improve the efficiency of their companies (Christainsen \& Haveman 1981). We analyze this in a toy model in which executives have to decide the optimal allocation of their limited time between competing tasks $a$ la Rosen 
(1982). Companies have two hierarchical levels in which one manager takes care of $n$ workers in which the number of workers is endogenously chosen by the manager. Managers have a limited amount of time available $\mathrm{T}$ that they have to spend on two tasks. First, managers supervise the innovation activity of its employees and by this they increase employees' productivity. Alternatively managers spend time in understanding or implementing regulatory changes. We start by assuming that the amount of time that each top executive commits to address regulatory issues is fixed and equal to $t_{R}$. This means that the rest of time total time $\mathrm{T}$ is devoted to help employees improving their efficiency.

As in Rosen (1982) managers differ in their quality levels. Workers also differ in their productivity. Let $q$ denote the quality of an individual manager and $L_{i}$ the quality of an individual worker. Each worker $i$ working for manager $q$ produces output $y_{i}$ according to the functional form:

$$
y_{i}=q^{\beta}\left(q t_{i}\right)^{\alpha}\left(L_{i}\right)^{1-\alpha}
$$

Where $t_{i}$ represents the amount of time that the executive has employed in helping worker $i$. Managers can work with many employees at the same time. Note that this will always happen because there is a decreasing marginal productivity of the time devoted to help a worker to innovate. As in Rosen (1982) the term $q^{\beta}$ in (1) is the analytical representation of the quality of general top-management decisions. It is independent of $i$, representing the effects of skills inherent in a command system which apply equally to all workers controlled by $q, q^{\beta}$ captures the indivisibility of management-type decisions as for example strategic issues and implies a scale economy because it improves productivity of all workers in the firm, irrespective of their numbers or the time allocated to them. Total firm output will be the sum of the individual output of all workers: $Y=\sum_{i=1}^{n} y_{i}$. The unit of skill of workers is paid a compensation of $w$.

With these assumptions the problem of the manager is to choose $t_{i} \forall i=1 \ldots n$ that maximizes:

$$
\sum_{i=1}^{n} q^{\beta}\left[\left(q t_{i}\right)^{\alpha}\left(L_{i}\right)^{1-\alpha}-w L_{i}\right]
$$

Subject to $\sum_{i=1}^{n} t_{i}+t_{r} \leq T$

This problem is identical to the model in Rosen (1982) with slight different notation and with the only exception of the extra time that manager have to devote to deal with regulatory problems $t_{r}$. We refer to Rosen (1982) for further details about the solution and further implications of this model. For our illustrative purposes is enough to point out that total production of a firm run by a manager of quality $q$ is:

$$
Y=q^{\beta} L\left(\frac{q\left(T-t_{r}\right)}{L}\right)^{\alpha}
$$


Where $L=\sum_{i=1}^{n} L_{i}$. Using (3) we can analyze the effect of the amount of general management quality on total factor productivity, taking logs in (3) to get:

$\log Y=\beta \log q+\alpha \log \left(q\left(T-t_{r}\right)+(1-\alpha) \log L\right.$

Hence total factor productivity, TFP, of a firm run by a manager of quality q would be:

$\beta \log q+\alpha \log \left(q\left(T-t_{r}\right)\right)$

Obviously $t_{r}$ decreases productivity since it decreases the amount of time that managers devoted to productive uses. Note also that with this specification the decrease in productivity is larger for the higher quality managers since precisely the opportunity cost of their time is the biggest. This would suggest that regulation intensity affects productivity asymmetrically, impacting more the most capable companies and therefore decreasing the skewness of the size distribution of firms in the economy. However this does not necessarily need to be the case and it is driven by the assumption that high quality and low quality managers devote the exact same time $t_{r}$ to regulatory issues. If more capable managers are able to deal with regulatory issues faster or more efficiently, then they could use less amount of time than not so capable managers. In this case regulatory intensity would affect comparatively more managers of lower quality and therefore it would increase rather than decrease the positive skewness of the size distribution of firms.

We illustrate this modifying the model above such that the amount devoted to regulatory issues is not constant across firms. For this we assume that the amount of time devoted to regulatory issues not only decrease the amount of time that managers could employ to help its workers but it also affects the amount of time that executives can dedicate to formulate management-type decisions like strategic firm issues that influence the productivity of all workers inside the firm. With this in mind we model the individual production function of worker $L_{i}$ that works for a manager of quality $q$ :

$$
y_{i}=\left(q-q R\left(1-t_{r}\right)\right)^{\beta}\left(q t_{i}\right)^{\alpha}\left(L_{i}\right)^{1-\alpha}
$$

Where $\mathrm{R}$ represents how costly is to deal with regulatory complexity and note that when $\mathrm{R}=0$ we are back to the previous case. Also, we impose the condition that $T \leq 1$ since we are interested in situations in which dealing with regulatory issues is costly (i.e. $\left.q R\left(1-t_{r}\right)>0\right)$.

From the first order conditions of a manager that maximizes profits we get:

$$
t_{r}^{*}=1-\frac{1}{R}+\frac{\beta L}{\alpha}
$$

(7) shows how the amount that top managers devote to regulatory issues is negatively related to R. With this modification now total output $Y_{2}$ becomes: 


$$
Y_{2}=(q R \beta L / \alpha)^{\beta} L\left(\frac{q\left(T-t_{r}^{*}\right)}{L}\right)^{\alpha}
$$

From (8) we can compute the new total factor productivity:

$$
T F P_{2}=\beta \log q+\beta \log \left(\frac{R \beta L}{\alpha}\right)+\alpha \log \left(q\left(T-t_{r}^{*}\right)\right)
$$

Note that since $\mathrm{T}<1$, then (7) implies that $R \beta L / \alpha<1$ and therefore if $t_{r}^{*}$ is close to $\bar{t}_{r}$ then $\mathrm{TFP}_{2}$ is lower than TFP. More interestingly note that the term $\alpha \log \left(q\left(T-t_{r}^{*}\right)\right)$ still indicates that more capable firms productivity are potentially more affected in their productivity by the regulatory burden. However the term $\beta \log (R \beta L / \alpha)$ shows how this can be compensated by the fact that managers of higher $q$ (and hence higher $L$ ) can also deal more efficiently with regulatory procedures and therefore enjoy higher productivity than less capable managers. The net effect is indeterminate and depends on the parameters of the model although in both cases productivity is decreased when managers are forced to give up valuable time in dealing with rules and regulatory procedures. In the empirical part of the paper we report evidence that supports that regulatory intensity affects proportionally more the largest (more productive) companies.

\section{DATA AND VARIABLE CONSTRUCTION.}

In this section we describe the dependent variables for TFP and innovation of the Spanish regions and the independent variable for regulation intensity variations among them. We also report the control variables that will be used in the regressions.

\subsection{Dependent Variables (I). TFP growth rate.}

We measure regional productivity of the Spanish regions by computing the growth of the total factor productivity (TFP) as described originally by Solow (1957) and further refined by Jorgenson \& Griliches (1967). This is a standard construct for productivity and it is profusely used in academia as well as in more policy oriented documents (for a review see Oliner, Sichel \& Stiroh 2007). Recent development and growth accounting studies have established that total factor productivity is an important source of cross-country differences in income per capita levels and growth rates (Hall \& Jones 1999). Intuitively, the TFP growth rate gauges the growth of output that cannot be explained by variations in the use if inputs and we hypothesize that this growth rate will be affected by regulation intensity as explained in the analytical framework. In general, improvements in TFP reflect contributions to output as a result of 
the more efficient use of resources or the adoption of new production technologies. More formally TFP growth rate of one region at year $t$ is derived as:

TFP Growthrate Git $=\frac{\Delta y_{i t}}{y_{i t-1}}-\left(1-\bar{\alpha}_{i t}\right) \frac{\Delta L_{t}}{L_{t-1}}-\bar{\alpha}_{i t} \frac{\Delta K_{t}}{K_{t-1}}$

Where $y$ represents total output, $L$ and $K$ are Labor and Capital inputs respectively and $\bar{\alpha}$ represents average share of capital. Since in discrete time the share of capital varies across time we take $\bar{\alpha}_{t}=\left(\alpha_{t}+\alpha_{t-1}\right) / 2$.

From official government statistics elaborated by the Instituto Nacional Estadística (INE), we get the time series of regional GDP as proxy for regional output. We download from INE the series of regional GDP at constant prices for the period 1988-2007. The INE reports the regional GDP from 1980 to 1995 with 1986 prices while regional GDP from 1996 to 2007 are reported with 1995 prices. We begin by normalizing the whole series to 1986 prices using the corresponding GDP deflator and then we compute the GDP growth rate at constant prices for each year. The average regional growth rate for the whole period is $2.8 \%$ with a standard deviation of $2 \%$. The maximum growth rate during the period was obtained by La Rioja with a 15\% growth rate in 1990 . The lowest growth rate was achieved by Castilla La Mancha in 1993 with a negative rate of $4.5 \%$.

Also from the same official source, INE, we obtain information of total number of people employed by region. The last year covered in the employment series is 2004 . We use this series to compute the growth in Labor input in (1). We compile regional changes in capital stock using regional historical series elaborated by the research department of one of Spain's largest private banks (Banco BilbaoVizcaya) ${ }^{1}$. This same series is used by most researchers that have computed the evolution of TFP growth rates across Spain's regions (Leonida \& Montolio 2004; Maudos et al. 2000; Prior Jiménez 1990) This series of capital stock is available from 1964 until 2004. Finally, we compute regional $\bar{\alpha}_{i t}$ as the fraction of total regional wage compensation over total regional GDP (both at constant market prices). The source of the variables is also the INE: With this information we are able to compute TFP growth rate for all seventeen regions for the period 1980 to 2004 .

Note that in this growth accounting exercise we are incurring in two relevant biases due to the limitations of our data. First, we would like to have constructed TFP using total number of hours worked

\footnotetext{
${ }^{1}$ This information can be freely downloaded at www.fbbva.es.
} 
as proxy of $L$ rather than total number of people employed. However, this information at the regional level does not exist for the long time interval that we need for our regressions. It could well be the case that the number of people employed increases across time but the number of hours worked per employee decreases. If so, we would be downwardly biasing our estimates of regional TFP. Second, given to lack of regional data, we are unable to adjust by changes in the quality of inputs. This can be important since Jorgenson \& Griliches (1967) show that a substantial fraction of the TFP can be explained by unmeasured improvements in both capital and labor inputs. Hence, as a result of this second limitation, we could be finding regional TFP estimators that are biased upwards. However, our purpose is not the appraise the "true" and accurate regional TFP growth rates but rather we want to assess whether TFP is affected by regional regulation. If so, these two biases may be ignored as long as their magnitude is not correlated with our proxies of regulatory intensity. A priori we do not see why changes in either the quality of inputs or in the number of hours worked by employee should be correlated with our regulatory intensity indexes and this is why we think that our results are not affected by measurement error in TFP growth rates. Yet in our empirical analysis below we try to address this potential problem using a instrumental variable that should not be correlated with neither of these measurement errors.

Table 1 displays our estimates of the average growth rates in this period for each region (SGC). The average regional GDP growth rate is around 3\% with the lowest average GDP growth rate corresponding to Asturias with only $1.92 \%$ while the maximum is obtained by La Rioja with $3.72 \%$. However, Table 1 suggests that most of this growth has been achieved without any increase in efficiency in the Spanish regions. The average TFP growth rate is quite close to zero in most of them and significantly negative in both the Balearic and Canary Islands, with a negative rate of around $1.4 \%$ and $1.18 \%$ respectively. Even with the limitations of our estimation of regional TFP that we have explained above, the finding of zero and even a negative trend of regional TFP that we find is consistent with the those by Prados de la Escosura \& Roses (2008) that for the period 1987-2000 and for the whole of the Spanish Economy report an average annual increase of TFP between negative $0.3 \%$ and positive $0.2 \%$.

\section{------Insert Table 1 around here------}

4.2. Dependent Variables (II) Regional Innovation: 
We obtain information on applications filed in the Spanish Patent and Trademark Office (Oficina Española de Patentes y Marcas) for Intellectual property rights (IPRs) that protect innovative activity. Registration is required to acquire a valid and legal IPR that can be exploited by business firms. This source provides annual information from 1990 to 2006 on four distinct measures of firm innovation activity at the regional level according to the address of the applicant. Despite well known discussion regarding the limitations of patent and IPRs counts as indicators of innovation and technological improvements, there is some general consensus on the relevance and value as a proxy for innovation and technological change (Griliches 1990).

Number of patents includes all applications for patents filed a given year from firms in a given region. A patent is a legal title recognizing the exclusive right during 20 years to make use of an invention, preventing others from manufacturing, selling or using it without the patent holder's consent.

Utility models includes all applications for "petty patents" or "innovation patents", presented by firms in each region to protect inventions of less inventive nature than those protected by patents, they require fewer conditions to be awarded than standard patents, they are cheaper to obtain, and when awarded they provide a shorter protection term (10 years).

Industrial designs includes all applications of legal protection for creative designs by firms addressed in one region, which gives their holder the exclusive right to use the appearance of the whole or a part of a product resulting from the features of, in particular, the lines, contours, colors, shape, texture and/or materials of the product itself and/or its ornamentation. Designs could be two-dimensional or three-dimensional. The protection conferred by industrial designs has a duration of 5 years from the filing date and can be renewed for one or more consecutive 5 years periods to a maximum of 25 years.

Trademarks measures all requests of legal title over brands filed by firms from each region, trademarks give the holder exclusive rights on a name or a sign for identifying a product, a service or a firm in the market. Although sometimes their layout may involve some creativity, we are aware that trademarks are used for identifying firms, products and business. However, they are a sensible indicator of the strength and dynamism of firm's economic activity and even productivity, constituting a good a proxy of new products, services or firms being launched in each region.

\subsection{Independent Variables.}


The goal of this paper is to estimate the impact of regulatory intensity on different innovation indicators. We proxy regulatory intensity both with the number of regional norms and the total number of pages occupied by the legislative and regulatory acts of general scope the regional governments have published in the exercise of their assumed powers. This is a raw measure of quantity of legislation that has the advantage that is totally objective and the disadvantage that totally disregards any attempt to measure the quality of the norms. Doubtless, the quality of the regulation has an effect on the impact of regulatory burden on any economic indicator and, therefore, our analysis below has two key identifying assumptions: a) For a given quality of the legislation, the lengthier the norm, the larger are the costs of compliance for economic agents and b) The quality of the regulation is negatively associated or not associated at all with the length of the regulation (i.e., in general terms, larger rules tend to have lower quality). If these assumptions do not hold, for example, because better regulations are longer, then our proxy based on the total number of pages would not be a good measure of regulatory burden and, therefore, we should expect to find no effect or positive effect on the economic indicators.

We measure the impact of regulatory activity of business with the number of pages and norms published by the Aranzadi Reporter of regional legislation and regulation for years 1988 to 2006. We use this 'rough' measure of regulatory activity because we consider that any attempt to elaborate a pure quantitative measure of regulation affecting economic activity can be criticized as imprecise or vague. It may suffer from roughness as any measure that goes without introducing any kind of valuation of content and effects of rules on business and economic activity, but it has the advantage of being completely unbiased.

Some attempts to construct indexes of regulatory burden are known. But they somehow betray the neutrality and objectiveness of quantitative measures, because they necessarily add some sort of judgment. For example, as mentioned before in the literature review, the OECD elaborates a Product Market Regulation Index, examining regulatory options and activity in different dimensions concerning product's markets in order to evaluate to what degree they inhibit or promote competition ${ }^{2}$. Our use of simple and objective measures of legislative production purports to preempt any criticism regarding the

\footnotetext{
${ }^{2}$ See Conway et al. (2005) stressing the "objective character" of the PMR index. It may be true that PMR indicators are designed and elaborated with a more objective methodology than other indexes, but nevertheless there is a "grain" of subjectivity in the evaluations that lead to their calculation (for example, why does it use the criteria it uses and no others?, how does it calculate the weight it gives to each of them?).
} 
subjectivity and bias that can be made of any content measure of regulation, and for that purpose it uses crude and pure quantitative measures. The main two indicators used will be the number of pages of the Aranzadi legislative collection published in each region and the number of different norms legislated by the regional parliaments and governments. We take the 18 years comprised in the period 1988-2005. The starting year is 1988 since this is the first year in which the Aranzadi legislative dataset provides information on all the regional norms in the same font and page format. In this framework we use four distinct proxies of regulatory intensity:

Number of pages at time $t$ measures the accumulated number of pages at time $t$ that the regions have written when exercising the powers under their jurisdiction. It is important to stress that the dataset provides this information in the exact same text, font and page format for all regions. As a result, differences in the number of pages are purely driven by differences in the length and number of norms. There are significant regional differences in the number of pages of legislation/regulation. In 2005 the region with the maximum number of "regulatory pages" issued was Catalonia with a total of around thirty thousand pages while Cantabria had only around nine thousand pages with the rest of regions located in the middle of these two extreme cases.

Number of Norms at time $t$ represents the accumulated number of norms legislated by the regions up to time $t$. Naturally the larger the number of norms approved, the higher the regulatory intensity. In the data we can observe huge regional dispersion in the number of norms adopted by region. For instance, while in 2005 Catalonia had already elaborated almost twelve thousand new regional norms, Cantabria, in the same year, had only developed around three thousand and four hundred new norms.

As explained above, the Spanish regions are not homogenous in terms of the powers they can exercise. This is true currently more than twenty-five years after the creation of the decentralized state, but this heterogeneity was much more pronounced in the earlier years of the creation of the decentralized State in which different regional paths to decentralization coexisted. Since we intend to use in our empirical analysis below time series data, we need to account by this different degree of regional empowerment because regions with more powers may naturally have more and/or lengthier norms, without this necessarily having any causal effect on regulatory intensity because the central state rules that the new regional regulation would be substituting is smaller. For this reason, we normalized number of accumulated pages by the total number of accumulated powers of the individual regions at any given year in our sample. This normalization has still the problem that not all powers assumed by the regions 
empower them in the same manner (i.e., it is different to assume and exercise powers on fisheries or agriculture than to do so on education or transportation), yet we see no reason why this may systematically bias our results.

Average number of pages per legal power at time $t$ is computed as the accumulated number of pages elaborated by a region at time $t$ divided by the number of legal powers under its jurisdiction at time t.

Average Number of Norms is computed as the total number of norms at time $t$ divided by the number of legal powers under the jurisdiction of the region.

\subsection{Controls}

\section{Population.}

In our analysis below we control by regional population levels, as more populated regions may display different legislative and economic trends. We have downloaded population data from the INE webpage. The INE webpage provides three different series of population. From 1986 to 1995 it provides a measure of regional population based on the number of inhabitants that were administratively registered in that region. From 1996 on the INE provides a measure of population based on the number of people that actually live in the region. We merge both series to build a unique population time series from 1986 to 2005. This means that the definition of population changes approximately in the middle period of our sample. As before, we do not believe this may cause any bias in the estimation of the effect of regulatory burden since we include year dummies in our regressions. Besides we are not interested in the estimation of the coefficient of the population variable and therefore the change of definition does not seem to be problematic. Finally, the INE does not provide population figures for the year 1997 and for this year we have used the population figures corresponding to the year 1996.

\section{Regional Gross Domestic Product (GDP).}

Standard neoclassical models (Barro \& Sala-i-Martin 2002) predict convergence in income per capita across regions. This convergence may imply that regions with larger GDP levels exhibit lower rates of productivity growth. If regions with larger economic size are characterized by a more intense regulatory activity then we could obtained a spurious negative association between productivity and 
regulatory activity if we do not control by regional GDP levels. The source of this control variable is explained above when we detail the sources for computing TFP growth rate.

\section{Regional Public Expenditure.}

We want to differentiate the effect of regulatory intensity from crowding out effects on private economic activity due to excessive public expenditure. With this in mind, we control in all our regressions by the annual level of public expenditure in constant prices incurred by regional authorities. The data we use in the analysis has been compiled by Spanish Ministry of Treasury (Ministerio de Hacienda) $)^{3}$. In non-reported results we have repeated all our analysis controlling by the number of regional government employees and by the fraction of regional public expenditure over total regional GDP. The results we obtain with these other controls are the same as the ones we display below.

\section{Regional and year dummies.}

Since the different regions vary in the sector distribution of economic activity, culture and language, the importance of other economic and civil institutions, the age distribution among the population and many other unobserved characteristics, we include in all our specifications regional dummies to account for all these regional differences. Finally, all our specifications include year dummies to take into account general national trends. Note that as a consequence of including year dummies all our results below can be interpreted as measuring the effect of local regulation on regional deviations from the national average.

Table 2 shows the descriptive statistics of all the variables described above as well as those that we will use later on in our empirical analysis.

\section{---Insert Table 2 around here---}

\section{DETERMINANTS OF OUR REGULATORY INTENSITY PROXIES.}

Since we have quite raw proxies of the intensity of regional regulation, we start by assessing informally whether the number of pages and the number of norms are correlated with different constructs that are likely associated to the existence of regulatory intensity and with the intervention of the public sector in the economy. With this purpose in mind, we first analyze whether both the number of pages and

\footnotetext{
${ }^{3}$ The information on regional public expenditure can be freely downloaded at http://www.estadief.meh.es.
} 
the number of regulatory norms correlate with other measures of public activity like the number of regional public employees and the amount of regional public expenditure. Intuitively, regions that stand out for their levels public expenditure and for their number of employees are likely to be those whose length and quantity of regulation is also larger. Table 3.a. and Table 3.b. displays the results of eight regressions in which the dependent variable is each one of our four measures of regulatory intensity and the dependent variables are (including regional and time dummies) the number of public employees, the percentage of public employees in the total population, the percentage of regional public expenditure over total GDP and the absolute levels of public expenditure. As additional controls we also include local population and total GDP levels. The coefficients displayed in Tables 3.a and 3.b show how both the number of pages and the number of norm of SGCs are strongly positively associated to all four measures of public activity (public employees, fraction of public employees of regional population, total public expenditure and fraction of public expenditure over regional GDP).

\section{------Insert Table 3.a and Table 3.b around here------}

Next, we check whether the number of pages and number of norms are associated to other more precise regulatory indexes. For this, we make use of a regional anti-competitiveness regulatory index constructed by the Spanish Competition authority (Tribunal de Defensa de la Competencia 2003). This index measures the obstacles to effective competition in retail trade and distribution arising from regulatory interventions by regional governments at that time. It identifies up to seven legal barriers to retail distribution: 1) The definition of the large retail establishment is based on its location; 2) There are multiple and arbitrary criteria to determine whether an establishment is large; 3) An establishment is considered large if more than 25 percent of its ownership belongs to a large firm; 4) There is a discriminatory treatment for discount retail establishments; 5) There are limits on the establishment of small retailers and transfer of their ownership; 6) Regional governments require a financial viability plan for commercial establishments to be authorized; and 7) There are outright bans on large retail establishments. The index added one point for each one of these legal barriers that were present in a given region. Although the maximum theoretical value of this anticompetitive regulatory index was seven points, the Spain Competition authority reported that the maximum value obtained was just four (corresponding to Catalonia, Baleares, País Vasco and Navarra and therefore being these four regions the ones with most obstacles to effective competition in retailing). On the contrary, Castilla La Mancha, with 
an index value of zero, is identified as the region with the lowest number of legal barriers to retail distribution.

\section{------Insert Table 4 around here------}

Table 4 displays the correlation coefficient of the anti-competitiveness regulatory index with our four proxies of regulatory intensity. In all four cases the correlation coefficient is positive and we can see that the correlation is statistically significant. We interpret Table 4 as evidence that those regions that through regulation have erected more legal barriers to competition in trade retailing are also those regions that have enacted a larger number of norms and had published a larger number of total "regulatory" pages (using different regulation indicators from the ones employed here, a similar result is found by Hoffmaister 2010 and De los Llanos Matea \& Mora-Sanguinetti 2009). Informally, this confirms the validity of our measures as proxies of regulatory intensity.

Once we have documented the positive cross section correlation between our proxies of regulatory intensity and the anticompetitive index in the retailing sector, we study the effect of our regulatory proxies on the evolution of the number of large retail establishments as well as in the total area devoted to large retailing outlets. We obtain information of both variables from a nonprofit foundation set up by $L a$ Caixa, one of Spain's largest saving institutions. This institution compiles information on large commercial outlets and their corresponding surface from 1996 until 2006. Because the legal definition of large commercial outlet varies in each region (according to several criteria, related to the commercial area), La Caixa follows the definition of the Spanish Association of commercial malls which does not require a minimum area for sales (it is defined as the "combination of independent commercial establishments, planned and developed by one or more entities, with the criterion of unity, whose size, business mix, common services and complementary activities are related to their environment, and that has an image permanently and management unit").

Since we have shown above that our proxies of regulatory intensity are strongly positively correlated to the number of legal barriers to competition in retailing, we are expecting to find a negative relation between length (and number) of regional norms and the total amount (and area) of large commercial outlets.

\section{------Insert Table 5.a and Table 5.b. around here-----}

Tables 5.a. (Table 5.b.) display the coefficients of four regressions in which the dependent variable is the number (and area) of large commercial outlets and the dependent variable is each one of 
our measures of regulatory intensity. Tables 5.a and 5.b show how all four measures of regulatory intensity are negatively associated to both number and total are of commercial outlets. All eight coefficients are statistically significant from zero. Note also that the magnitude of the effect is quite relevant. For example, in Table 5.a. the estimated coefficient of the variable Number of Norms implies that an increase of 100 percent in the number of local norms is associated to a decrease of 244 percent in the number of large commercial outlets. Similarly, according to Table $5 . \mathrm{b}$ an increase of $100 \%$ in the number of norms translates in a reduction of $205 \%$ in the total area devoted to large commercial outlets. Similar striking numbers can be inferred from the rest of coefficients in Tables 5.a and 5.b. Overall, we interpret both tables as strong evidence that both the number and length of norms is associated with diminishing presence of large commercial outlets and hence with lower competition at the retailing sector.

\section{REGULATION AND INNOVATION.}

Once we have established the validity of our proxies for regulatory intensity, in this section we perform an analysis concerning the association between regulation intensity and other variables that according to standard arguments are likely connected to the evolution of business innovation.

\section{---Insert Tables 6.a, 6.b, 6.c, 6.d and 6.e around here---}

Tables 6.a to 6.e show the results of 20 regressions in which the dependent variables are each one of our five measures of firm innovation and the independent variables are our four different measures of regulatory intensity plus controls. Note that all 20 coefficients show a negative relation between the measures of industrial innovation and the regulatory intensity, 16 out of 20 coefficients are statistically different than zero. Moreover, both the variables that measure the number of norms and number of norms per legal power over which regional governments have jurisdiction, all of them without exception, are statistically significant. The economic magnitudes are substantial. The coefficients associated to the number of norms suggest that an increase of $100 \%$ in the number of regional norms is associated to a decrease in the trademark applications of 61 to $63 \%, 101$ to $103 \%$ of utility models applications, 79 to $81 \%$ of patent applications, 111 to $122 \%$ of trade names applications and 62 to $113 \%$ of industrial designs applications. Overall we interpret Tables 6.a. to 6.e. as strong evidence that regulatory intensity is associated to a substantial diminishing in business innovation activities (R\&D). 


\section{REGULATION AND PRODUCTIVITY GROWTH.}

We start this section by exploring the evolution of regional total factor productivity growth rate in 1980-2004.

Graph 1 shows how evolution has differed in two groups of regions. The first/second group includes all regions with the largest/lowest increase in the number of pages of legislation normalized by the respective powers assumed by each region.

\section{-------Insert Graph 1 over here--------}

Although the TFP growth rate shows a tremendous variation over the years, we can observe that there is not a tendency to have positive growth for none of the groups and this is consistent with the averages displayed in Table 1 that showed that productivity did not grow in Spain during the period we study. However in graph 1 we can see that those regions with the lowest increase in regulation in 19882003 seem to have slightly better TFP growth rates during that period. On the contrary, those regions with the largest increase in regulation in 1988-2003 seem to perform slightly better in the period immediately before: 1980-1986. Table 7 reaffirms this graphical intuition by showing the average annual growth rate for those regions with the largest/lowest increase in regulation in both subperiods. Those regions that have regulated the most in 1988-2003 underperform lowest performing regions in the period of study while they outperformed them in the previous eight years.

\section{------ Insert Table 7 around here---}

Better evolution of productivity in regions with the lowest increase in regulation displayed in Table 7 could be driven by a variety of reasons like differences in the economic development, industry composition, or demographics that could be associated at the same time with the intensity of regulation and the evolution of productivity. We rule out the alternative explanations by estimating a fully fledged econometric specification. Note that given that we have only information on the stock of capital per region until the year 2004, our analysis comprises now the period 1988 to 2004.

\section{------ Insert Table 8 around here---}

Table 8 displays the results of four regressions in which the dependent variable is TFP growth rate over our four measures of regulatory intensity. Consistent with the preliminary findings that we have just reported, the number of norms is negatively associated to TFP growth rates and the two corresponding coefficients are statistically different than zero. Their magnitude implies that doubling the number of norms would be associated to a decrease in the TFP growth rate of around 3.5\%. Given that the average 
TFP growth rate during the period is $-0.15 \%$ this estimates show that productivity slowdown in the Spanish Economy during the period could have been avoided by lowering legislative and regulatory activity of regional parliaments and governments. The results of Table 8 show also a negative sign of the number of pages of regulation on TFP, but only marginally significant, that suggests that the number of norms rather than the pure length of the norms encumber regional TFP.

\section{ROBUSTNESS TESTS.}

As it occurs always with any empirical work, the correlations identified in Tables 6 and 8 need to be interpreted with caution since they could be driven by some misspecifications of the empirical model unrelated to any causal effect and in particular by the endogenous nature of our regulatory intensity variables. For that reason, we perform some robustness test to better assess the nature of the linkage between regulatory intensity, innovation and TFP. First we show the robustness of our results to the use of lagged independent variables, second we exploit the characteristics of the Spanish decentralization process to perform an instrumental variable analysis that check whether our result are driven by the endogeneity of local regulation.

We start by ruling out that the quantity of regulation can be negatively correlated to innovation or TFP due to standard omitted variable bias. For example, it could be the case that regulation quantity increases the last year of activity of regional parliaments just before regional elections. At the same time, local economic agents could postpone investment or important economic decisions until knowing the color of the winner party. Similarly, it could be the case that when economic indicators deteriorate, local politicians felt the impulse to change and increase the levels of regulation. If so, the negative correlations reported in Tables 6 and 8 might be driven by either this "election year" effect or the "crisis reaction" effect and therefore unrelated to any cause-effect relation between regulation and both innovation and productivity. We rule out that the reported negative correlations are driven by any unobserved contemporaneous effect by replication our main regressions lagging one year our proxies of regulatory intensity. 
Table 9 replicates our previous results but studying the effect of regulatory intensity at time $t-1$ on TFP, retail competition, patent and trademarks applications at time $t^{4}$. The coefficients on Table 9 show that our results do not change when using lagged regulatory intensity variables indicating that the negative effect of regulation is not driven by omitting variable bias due to unobserved contemporaneous effects like the "election year" effect or the "crisis reaction" effect.

Another possibility could be that regional governments do not only react to poor economic conditions but also they intervene when they properly forecast that productivity is going to experience a slowdown. If so, local governments would increase their regulatory activity to diminish the negative effects of the predicted slowdown. This phenomenon is an alternative interpretation of the results displayed in Table 8 that have nothing to do with a negative effect of regulation on productivity. For ruling out this alternative explanation, we need an instrumental variable that is related to regional regulatory intensity and at the same time totally unrelated to productivity shocks or other variations in economic conditions. Fortunately, the continuous and progressive process of decentralization in Spain provides an excellent instrument that satisfies both conditions. As briefly explained above, the allocation and transfer of powers to regional authorities have been happening gradually in the last thirty years depending on both the political situation of the governing political parties both in the Spanish Central State and in each the regions and, in particular, the necessity of the ruling party at central state level of political alliances for getting support by the regional parties that have representation in the national parliament. Moreover the decentralization process has been conditioned by internal political struggles of the national party in power as well as by internal political struggles at the regional level. This has resulted in a decentralization process that exhibits a remarkable degree of variation across time and across the different regions (see López Laborda \& Vallés Giménez 2006 attempt to model the forces explaining different regulatory strategies by Spanish regions). Annex A displays the detailed time evolution of the transfer of powers by region. Roughly speaking we can identify two main periods of regional empowerment: 1982-1985 that coincides with the period in which most regional governments were being created and the mid 1990s in which there was a new wave of state decentralization. Also, note that almost every single year new powers are assigned to regions in an heterogeneous manner producing distinct

\footnotetext{
${ }^{4}$ In Table 9 we do not include the results of industrial designs, industrial utilities and industrial names for expositional purposes. The results with these three variables and with lagged regulatory intensity are qualitatively the same as the results we have shown in Tables 6.a. to 6.e.
} 
paths of decentralization and hence of exogenous regional variations that we exploit in our empirical analysis.

Naturally, the degree of decentralization is positively related to the amount of regional regulation and, given its political nature, is unrelated to the economic conditions or predicted productivity. This makes the degree of political power allocated at each point in time to each individual regional government a magnificent instrument to check that our results are not driven by the endogeneity of the regulatory activity.

With this purpose we instrument our regulatory variables with the number of powerss that they have a given year $t$. More formally we implement the following two stage instrumental variable estimations: In the first stage we estimate a lineal regression of the form

$$
\text { Regional intensity }_{i t}=\beta_{1} \text { Local Competency } \text { Cot }+\beta_{x} X_{i t}+u_{i t}
$$

Where Regional Intensity could be either the number or length of local norms, local power is the number of distinct issues in which region $i$ is allowed to regulated and $\mathrm{X}$ are other controls (Regional and Year dummies, GDP, Population and Regional Public Expenditure). As a second step, we estimate.

$$
T F P_{i t}=\beta_{2} \overline{\text { Regulatory Intensity }}_{i t}+\beta_{x} X_{i t}+e_{i t}
$$

Where

$\overline{\text { Regulatory Intensity }}_{i t}$ is the estimated value of the first step, this is:

$$
\overline{\text { Reglonal Intensity }}_{i t}=\hat{\beta}_{1} \text { Local Power }_{i t}+\hat{\beta}_{x} X_{i t}+u_{i t}
$$

Where $\widehat{\beta_{1}}$ and $\widehat{\beta_{x}}$ are estimators of $\beta_{1}$ and $\beta_{x}$ found running ordinary least squares regressions in the first stage. Naturally the second stage adjusts the standard errors to take into account that Regulatory Intensity is now an estimated variable. Finally, note that we cannot use this instrumental variable approach to our measures of regulatory intensity that adjust by the number of powers assumed by each region since mechanically these averages depend negatively on the number of powers. The results of this two-stage-least-square estimation process are displayed in Table 10.

\section{------ Insert Table 10 around here------}

Table 10 shows how the Instrumental Variable estimation provides evidence that an exogenous increase in the number of regional regulation is associated to lower TFP growth rates. If we compare the results in table 10 with those displayed in Table 8 we find that accounting for the endogeneity of the regulatory process provides even stronger estimate of the effect of regulatory intensity on TFP growth rate. The fact that the negative effects displayed in the IV estimators in Table 10 are even stronger than 
the OLS estimates of Table 8 suggest that, without correction, endogeneity is downwardly biasing the assessment of the negative effect of regulatory intensity on productivity. This could happen if -as suggested in Table 8- regions with higher productivity are those that decide to regulate more intensively.

The IV estimations suggest that doubling the number of local norms translates in a decrease of TFP growth rate of around $5.5 \% \%^{5}$. More significantly, now the coefficient on the number of pages of regulation is statistically significant and its magnitude also suggests that an increase of $100 \%$ in the number of pages is associated likewise to a decrease of around 5.5\% in the regional TFP growth rate.

\section{LINK BETWEEN PRODUCTIVITY-INNOVATION AND REGULATION.}

In the previous sections we have documented a strong negative relation between regulation intensity and regional productivity and innovation. In this section we explore potential explanations for this negative association. Section 3 explained two main causal mechanisms to explain the association between regulation and productivity: regulatory distortions in product market competition and generic distortions in the optimal allocation of resources. In this section we explore both; first we investigate the effect of regulatory intensity on the number of business establishments to observe whether regulation has raised barriers to entry and consequently reduced product competition in the marketplace. Second, we analyze the existence of regulation-driven changes in the regional size distribution of business establishments. These changes in the size distribution would be consistent with regulatory intensity affecting asymmetrically firms depending on its size.

For this purpose we compile information from the INE about the number of business establishments in all industrial sectors per region. The INE freely offers a dataset called DIRCE (Directorio Central de Empresas) with information on the number of business establishments per region of 289 distinct industrial sectors. This information can be downloaded from the INE webpage. Unfortunately this data is accessible only since 1999 and, therefore, we cannot replicate the same time period as in our main analysis that starts in 1988. On the contrary, we are able to expand the analysis a couple of additional years after 2004 and hence the time period of this additional test runs from 1999 to 2006. We run a fully fledged econometric specification quite similar to the one displayed above. This is,

${ }^{5}=0.08 * \log (2)$ 
we run regressions in which the dependent variable is the natural log of the number of establishments, the independent variables are our proxies of regulatory intensity and we control by 289 industry dummies, 17 regional dummies, six year dummies and regional GDP, population and public sector expenditure. The results are displayed on Table 11.

\section{------ Insert Table 11 around here---}

In Table 11 we can see that all four variables of regulatory intensity have a negative sign but they are not statistically different than zero under standard significance tests. From these results we cannot conclude that regulatory intensity generically increases barriers to entry and hence restricts competition, although this can certainly happen with some regulation in particular industries as we have shown in Table 5.a with the number of large commercial outlets. Therefore, we conclude that we do not find evidence supporting that the decrease in innovation and productivity levels is driven by decreased competition caused by higher barriers to entry.

Next, we study whether regulation has affected the allocation of resources within the industry. According to the arguments developed supra in the description of our analytical framework (section 3), this could imply that regulation systematically affect in greater extent the more productive companies and hence this could imply that resources are being transferred from the less productive to the more productive units of production. If so, this should have an effect on the size distribution of establishments as discussed in analytical section. We explore this potential effect of regional regulation on the size distribution of companies using again information from DIRCE. DIRCE not only reports annual number of business establishments per industry, region and year but also differentiates within these categories the number of business establishments according to the number of employees they have. More particularly, this dataset categorizes the number of business establishments per industry, region and year in 9 categories. These categories are displayed in Table 12.

\section{------ Insert Table 12 around here---}

Unfortunately DIRCE does not report the extent of sales or employees controlled by each business establishment such that we could value the size distribution of establishments at the regional level that we would need for our purposes. However, for this purpose we cross the information contained in the DIRCE dataset with another dataset available, the so-called the Encuesta Industrial de Empresas (freely available from the INE). This dataset reports number of people occupied per region-year in 12 industries. These 12 
sectors have an automatic equivalence with two digit CNAE industries and, therefore, for these 12 sectors we can cross them with the DIRCE dataset without error. The only major drawback is that these 12 sectors are exclusively industrial sectors and, therefore, we are abstracting out from any distortionary effect that regulatory intensity may have on services or agriculture. Moreover since the Encuesta Industrial de Empresas reports total number of occupied people and not the total number of employees we multiply the total number of occupied people in any given region-industry-year by the percentage of occupied that are employees per region-year in the industrial sector. This percentage is extracted from the dataset Contabilidad Regional (CRE, freely available also from the INE).

We compute the size distribution of establishments by assuming that the average establishment in each bracket of working force has a number of employees equal to the lower bound of the bracket except for the establishments within the bracket of 500 employees or more. For instance we assume that the average establishment with 5 to 9 employees has 5 workers on its payroll. For those establishments with 500 employees or more we found the average number of workers such that the total number of employees equals the total number of employees in the industry-region-year. The resulting average number of employee per type of establishments is reported in the second column of Table 12. Note that the average number of workers of those establishments with more than 500 employees is 2857.

We have also tried considering different average employees per establishment (other than the lower bound) such that the middle point in the bracket ( 7 employees in our previous example) and the upper bound of the bracket ( 9 employees in our previous example) but with this procedure we were finding a significant number of industries-region-year in which total number of employees was superior to the total number of people occupied and, since this would contradict reality, this is why we finally chose the lower bound of the bracket. This solution certainly has some drawbacks since we are assuming that the all establishments in the same bracket have the same number of employees. However we do not believe this constitutes an important problem for our purposes because we are not interested in the distribution per se but rather in how it is affected by changes in regulatory intensity. Thus, we do not see any reasons why that would be correlated with this type of measurement error.

Graph 2 explores how the percentage of employees working for the largest establishments in the DIRCE dataset has changed in 1999-2006 according to how much regional regulatory intensity increased in the same period. Graph 2 shows how, apparently, those regions with the largest jump in the number of 
new norms are those in which there has been a largest decrease (or a lowest increase) in the percentage of activity of the largest business establishments.

\section{-Insert Graph 2 around here}

Next we explore whether this alleged negative correlation holds in fully fledged econometric models. For this goal we run panel data regressions for the period 1999-2006 with 1766 industry-regionyear observations in which the dependent variable is the percentage of employees working for the largest establishments and the dependent variables are our proxies of regulatory intensities introducing control variables for regional GDP, regional population, regional public expenditure, regional dummies, year dummies and industry dummies. The results are displayed in Table 13.

------ Insert Table 13 around here--- 
The estimates displayed in Table 13 show how the intuition we could extract from Graph 2 is confirmed once we control by a myriad of factors. Both the number of regional norms and the number of regional pages of regulation is associated negatively with the percentage of employees working for establishments with at least 500 employees. Similarly, regulatory intensity is negative associated to the proportion of employees working for establishments with 250 employees or more although in this latter case this relation is only marginally significant for the number of norms.

The negative association between regulation intensity and the percentage of activity controlled by large firms displayed in Table 13 and Graph 2 should have a negative effect on the skewness of the regional size distribution of firms. Following Rossi-Hansberg \& Wright (2007), we estimate how the local size distribution of companies varies with regulation intensity. Following their methodology we first compute a new variable $P_{i k j}$ that represents the proportion of establishments that in region $i$, industry $k$ have employment larger than $n_{j}$. Note that given the limitations of DIRCE dataset we have only 9 possible values for $n_{j}$. Graph 3.a and Gpah 3.b represents how this probability distribution has varied in 19992006 in those regions with the largest and lowest increase in regulatory intensity.

\section{--Insert Graph 3a and $3 b$ around here-}

Although in both groups we can see that the $P_{j}$ of the largest type of establishments has decreased ${ }^{6}$, it is clear comparing both graphs that the drop is largest for those regions with the largest increase in regulatory intensity. This is consistent with the previous findings that regulation intensity has affected relatively more the largest establishments. Once more we explore whether this intuitive finding holds in detailed econometric specifications and following the methodology proposed by Rossi-Hansberg \& Wright (2007) we run the following regression:

$\log P_{i k j}=a_{i k}+b_{i k} \log n_{i k j}+\gamma\left(\log n_{i k j}\right)^{2}+\beta *$ RegIntensity $\left(\log n_{i k j}\right)^{2}$

Where, as before, $P_{i j}$ represents probability in industry $j$ in region $i$ of having a business establishment with more than $n_{i j}$ employees; and $a_{i j}$ and $b_{i j}$ are industry-regional parameters. If regulatory

\footnotetext{
${ }^{6}$ Note that since our largest size bin is those establishments with 500 employees or more the corresponding pj of these establishments is 0 and therefore they are not graphed in Graphs 3a or $3 \mathrm{~b}$.
} 
intensity affects negatively the skewness of the size distribution we should expect that $\beta$ is negative. Table 14 displays the estimates of $\beta$ for the two cross sections corresponding to the year 1999 and 2006 and also for the pooling regression of the eight years in the interval. In all specification $\beta$ estimates are negative and significant confirming the finding of Table 14 that regulation intensity affects relatively more the largest business establishments. Given that Giuri et al. (2007) shows how innovation is concentrated in those companies with at least 250 employees these last results suggest that the drop in innovation and productivity associated to larger levels of regulatory intensity can be explained by an asymmetric effect of regulation that affects precisely the most innovative companies.

\section{------ Insert Table 14 around here---}

\section{CONCLUSIONS.}

In this paper we show how the process of decentralization in Spain has resulted in a wide dispersion of the quantity of regulation in the different regions (Self Governing Communities). We make use of this cross- sectional variation to estimate the effect of distinct paths of regulatory intensity on regional productivity and innovation. We find that the total number of "regulatory pages" published and the total number of norms each region has adopted has an important negative effect. Our estimates show that an increase of $100 \%$ in the number of norms is associated with a decrease of $79-81 \%$ in the number of regional patent applications and a lower TFP growth rate of around 3.5\%. Given that the average TFP growth rate during the period is $-0.15 \%$ this estimates show that productivity slowdown in the Spanish economy during the period could have been avoided if regional governments would had undertaken a much lower regulatory activity. We do not find evidence supporting that this decrease in productivity is caused by lower product market competition at the regional level. However we find some indication that regulatory intensity affects firms asymmetrically and therefore distorts the optimal allocation of resources. More regulation intensity affects negatively the proportion of resources controlled by business establishments with 200 employees or more and this extra burden precisely to the more innovative companies may explain the negative linkage between regulation and productivity. 


\section{REFERENCES}

Aghion, Philippe; Nick Bloom; Richard Blundell; Rachel Griffith \& Peter Howitt (2005): «Competition and Innovation: An Inverted-U Relationship», The Quarterly Journal of Economics, 120(2): 701-728.

Alesina, Alberto; Silvia Ardagna; Giuseppe Nicoletti \& Fabio Schiantarelli (2005): «Regulation and Investment», Journal of the European Economic Association, 3(4): 791-825.

Blanchard, Olivier \& Francesco Giavazzi (2003): «Macroeconomic Effects of Regulation and Deregulation In Goods and Labor Markets», The Quarterly Journal of Economics, 118(3): 879-907.

Balmaseda Del Campo, Manuel (2004): «Instituciones, regulación y productividad», in EuropaEstados Unidos: flexibilidad, crecimiento y bienestar. Libro Marrón 2004, Círculo de Empresarios, Madrid, 27-44.

Balmaseda Del Campo, Manuel \& Angel Melguizo Esteso (2006): «Mejor regulación, ni más ni menos», in Marco Regulatorio y Unidad de Mercado. Libro Marrón 2006, Círculo de Empresarios, Madrid, 15-35.

Barro, Robert J. \& Xavier Sala-i-Martín (2002): Economic Growth, $2^{\text {nd }}$ ed., The MIT Press, Cambridge (Mass.).

Christiansen, Gregory B. \& Robert H. Haveman (1981): «Public regulations and the slowdown productivity growth», American Economic Review Papers \& Proceedings, 71 (2): 320-325.

Conway, Paul; Véronique Janod \& Giuseppe Nicoletti (2005): «Product Market Regulation in OECD Countries: 1998 to 2003», OECD Economic Department Working Papers $n^{\circ} 419$, available at http://www.olis.oecd.org, visited 15.07.10)

Dawson, John. W. (2007): «Regulation and the Macroeconomy», Kyklos, 60(1): 15-36.

Dawson, John W. \& John J. Seater (2007): «The Macroeconomic Effects of Federal Regulation», Working Paper, Appalachian University, May available at http://econ.appstate.edu/RePEc/pdf/wp0516.pdf, visited 15.07.10).

De los Llanos Matea, María \& Juan S. Mora-Sanguinetti (2009): «Developments in Retail Trade Regulation in Spain and their Macroeconomic Implications», Banco de España, Documento de Trabajo $\mathrm{n}^{\circ} 0908$ (available at http://www.bde.es/informes/be/docs/dt0908e.pdf, visited 15.07.10).

Djankov, Simeon; Caralee McLiesh \& Rita Ma Ramalho (2006): «Regulation and growth», Economics Letters, 92(3): 395-401.

Dufour, Charles; Paul Lanoie \& Michael Patry (1998): «Regulation and productivity», Journal of Productivity Analysis, 9: 233-247.

Giori, Paula; Myriam Mariani; Stefano Brusoni; Gustavo Crespi; Dominique Francoz, Alfonso Gambardella; Walter Garcia-Fontes; Aldo Geunac, Raul Gonzales; Dietmar Harhoff; Karin Hois; Christian Le Bas; Alessandra Luzzi; Laura Magazzini; Lionel Nesta; Önder Nomaler; Neus Palomeras; Pari Patel; Marzia Romanelli; Bart Verspagen (2007): «Inventors and invention processes in Europe: Results from the PatVal-EU survey», Research Policy, 36 (8): 1105-1106.

Glaeser, Edward L.; Rafael La Porta; Florencio López-de-Silanes \& Andrei Schleifer (2004): «Do Institutions Cause Growth? », Journal of Economic Growth, 9(3): 271-303.

Gollop, Frank M. \& Mark J. Roberts (1983): «Environmental Regulations and Productivity Growth: The Case of Fossil-Fueled Electric Power Generation», Journal of Political Economy, 91/4: 654674.

Gray, Wayne B. (1987): «The Cost of Regulation: OSHA, EPA and the Productivity Slowdown», American Economic Review, 77/6: 998-1006.

Gørgens, Tue; Martin Paldam \& Alan Wurth (2003): «How does public regulation affect growth? ", University of Aarhus Department of Economics Working Papers, $\mathrm{n}^{\circ}$ 2003-14 (available at ftp://ftp.econ.au.dk/afn/wp/03/wp03 14.pdf, visited 15.05.10).

Griliches, Zvi (1990): «Patent statistics as economic indicators: a survey», Journal of Economic Literature, 28: 1661-1707.

Gual, Jordi; Sandra Jódar Rosell \& Àlex Ruiz Posino (2006) «El problema de la productividad en España: ¿Cuál es el papel de la regulación?», Documentos de Economía "La Caixa” n 1, june (available at http://www.pdf.lacaixa.comunicacions.com/de/esp/de01_esp.pdf, visited 15.07.10).

Hall, Robert D. \& Charles I. Jones (1999): «Why Do Some Countries Produce so Much More Output per Worker Than Others?», The Quarterly Journal of Economics, 114(1): 83-116.

Hsieh, Chang-Tai \& Peter J. Klenow (2009): «Misallocation and Manufacturing TFP in China and India», The Quarterly Journal of Economics, 124(4):1406-1448.

Hoffmaister, Alexander W. (2010): «Barriers to Retail Competition and Prices: Evidence from Spain», Oxford Economic Papers, 62(2): 395-416. 
Jalilian, Hossein; Colin Kirkpatrick \& David Parker (2007): «The Impact of Regulation on Economic Growth in Developing Countries: A Cross-Country Analysis», World Development, 35(1): 87103.

Jorgenson, Dale W. \& Zvi Griliches (1967): «The explanation of Productivity Change», Review of Economic Studies, 34: 249-280.

Lele, Priya P. \& Mathias M. Siems (2007): «Shareholder protection: A Leximetric Approach», The Journal of Corporate Law Studies, 7(1): 17-50.

Leonida, Leone \& Daniel Montolio (2004): «On the determinants of convergence and divergence processes in Spain», Investigaciones Económicas, 28(1):89-121 (available at ftp:/ftp.funep.es/InvEcon/paperArchive/Ene2004/v28i1a4.pdf, visited on 15.07.10).

López Laborda, Julio \& Jaime Vallés Giménez (2006): «Factores Explicativos de la actividad reguladora de las Comunidades Autónomas (1989-2001)», IEF, Papeles de Trabajo 9/06 (available at www.ief.es/Publicaciones/PapelesDeTrabajo/pt2006 09.pdf, visited 15.07.10).

Loyaza, Norman V.; Ana M $\mathrm{M}^{\mathrm{a}}$ Oviedo \& Luis Servén (2004): «Regulation and Macroeconomic Performance», World Bank WPS 3469, Sept. (available at http://ssrn.com/abstract=643682, visited 15.07.10).

Marcos, Francisco; Juan Santaló \& Albert Sánchez Graells (2010): «Measuring Regulatory Intensity by the Spanish Regions (1978-2008)», WP-IE Business School.

Maudos, Joaquín; José. Manuel Pastor \& Lorenzo Serrano (2000): «Crecimiento de la productividad y su descomposición en progreso técnico y cambio de eficiencia: una aplicación sectorial y regional de España (1964-1993)", Investigaciones Económicas 24/1, 177-205 (available at ftp://ftp.funep.es/InvEcon/paperArchive/Ene2000/v24ila6.pdf, visited 15.07.10).

Nickell, Stephen J. (1996) «Competition and Corporate Performance», Journal of Political Economy, 104(4): 724-746.

Nicoletti, Giuseppe (2001) «Regulation in Services: OECD Patterns and Economic Implications», OECD Economics Department Working Papers 287 (available at http://www.oecdilibrary.org/oecd/content/workingpaper/223766183220, visited 15.07.10).

Nicoletti, Giuseppe; Andrea Bassanini; Ekkehard Ernst; Sébastien Jean; Paulo Santiago \& Paul Swaim (2001): «Product and Labour Markets Interactions in OECD Countries», OECD Economics Department Working Papers 312 (available at http://www.oecdilibrary.org/oecd/content/workingpaper/814240442882, visited 15.07.10).

Nicoletti, Giuseppe \& Scarpetta, Stefano (2003): «Regulation, productivity and growth: OECD evidence», Economic Policy, 18(36): 9-72.

Prados de la Escosura, Leandro \& Joan R. Rosés (2008): «Proximate causes of economic growth in Spain, 1850-2000», Working Papers in Economic History, 08-12, U. Carlos III, Departamento de Historia Económica e Institucione (available at http://e-archivo.uc3m.es/bitstream/10016/2735/5/wp-0812.pdf, visited 15.07.10).

Oliner, Stephen D.; Daniel E. Sicher \& Kevin J. Stiroh (2007): «Explaining a Productive Decade», Brooking Papers on Economic Activity, 38: 81-152.

Prior Jiménez, Diego (1990): «La productividad industrial de las Comunidades Autónomas», Investigaciones Económicas, 14/2: 257-267 (available at $\mathrm{ftp} / / / \mathrm{ftp} . f u n e p . e s / I n v E c o n / p a p e r A r c h i v e /$ May1990/v14i2a5.pdf, visited 15.07.10).

Restuccia, Diego \& Richard Rogerson (2008): «Policy Distortions and Aggregate Productivity with Heterogeneous Plants», Review of Economic Dynamics, 11 (4): 707-720.

Rosell Lastortras, Juan (2006): «La regulación: su cuantía y su coste», Actualidad Jurídica Uría Menéndez, 14: 7-12 (available at http://www.uria.com/esp/actualidad juridica /n14/tribuna.pdf, visited 15.07.10).

Rosen, Sherwin (1982): «Authority, Control, and the Distribution of Earnings», Bell Journal of Economics, 13: 311-327,

Rossi-Hansberg, Esteban \& Mark L. J. Wright. (2007): «Establishment Size Dynamics in the Aggregate Economy», American Economic Review, 97 (5): 1639-1666.

Siems, Mathias M. (2005): «Numerical Comparative Law: Do we need Statistical Evidence in Law in order to reduce complexity?», Cardozo Journal of International \& Comparative Law, 13: 521-540.

Solow, Robert (1957): «Technical Change and the Aggregate Production Function», The Review of Economics and Statistics, 39:312-320.

Tribunal de Defensa de la Competencia (2003): Informe sobre las Condiciones de Competencia en el Sector de la Distribución Comercial (Report on the Competition conditions in the retrail trade sector) (available at http://www.cncompetencia.es, visited 15.07.10). 
Vallés Jiménez, Jaime (2005): « La reforma de la regulación en el contexto autonómico», Instituto de Estudios Fiscales-Papeles de Trabajo, 5/05 (available at ¡Error! Referencia de hipervínculo no válida, visited 15.07.10).

Vallés Jiménez, Jaime \& Anabel Zárate Marco (2006): «Reflexiones en torno al debate del impacto económico de la regulación y los procesos institucionales para su reforma», Tribuna de Economía ICE, 829: 205-233 (available at http:/www.revistasice.com/Estudios /Docu men/ice/829/ICE8290203.PDF, visited 15.07.10).

Zárate Marco, Anabel \& Jaime Vallés Jiménez (2010): «The cost of regulation in a decentralized context: the case of the Spanish regions», European Journal of Law and Economics, forthcoming (available at http://springerlink.com/content/001t410807v240u2 /fulltext.pdf, visited 15.07.10). 


\section{APPENDIX A}

SUMMARY OF THE TRANSFER OF POWERS BETWEEN THE

CENTRAL GOVERNMENT AND THE SELF-GOVERNING COMMUNITIES

\begin{tabular}{|c|c|c|c|c|c|c|c|c|c|c|c|c|c|c|c|c|c|c|c|}
\hline & 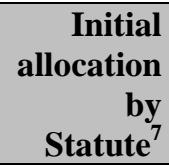 & 1978 & 1979 & 1980 & 1981 & 1982 & 1983 & 1984 & 1985 & 1986 & 1987 & 1988 & 1989 & 1990 & 1991 & 1992 & 1993 & 1994 & 1995 \\
\hline Andalucía & 89 & & 2 & & 8 & 10 & 28 & 22 & 10 & 5 & 2 & & & 7 & & 4 & & & 10 \\
\hline Aragón & 63 & & 3 & & 4 & 9 & 14 & 16 & 5 & 2 & 1 & & & & & 3 & 4 & 7 & 14 \\
\hline P. Asturias & 44 & & 1 & & 3 & 12 & 17 & 12 & 8 & 2 & 1 & & 3 & & & & & 5 & 15 \\
\hline Baleares & 77 & & 2 & 1 & 3 & 9 & 14 & 13 & 6 & 3 & 1 & & & & & 1 & 7 & & 19 \\
\hline Canarias & 36 & & 1 & & 3 & 4 & 21 & 15 & 17 & 5 & 1 & 1 & & 7 & & & 2 & 5 & 12 \\
\hline Cantabria & 43 & & & & & 16 & 19 & 9 & 6 & 3 & & & & & & & & & \\
\hline Castilla-La Mancha & 48 & & 1 & & 3 & 11 & 20 & 11 & 8 & & 2 & & 3 & & & & 2 & & 14 \\
\hline Castilla \& León & 43 & & & & 6 & 10 & 14 & 14 & 9 & 1 & 4 & & 3 & & & & 3 & 7 & 9 \\
\hline Catalonia & 89 & 5 & 2 & 13 & 21 & 12 & 11 & 7 & 8 & 3 & 5 & & 6 & 1 & 5 & 4 & & 6 & 10 \\
\hline Extremadura & 43 & & 1 & & 3 & 10 & 17 & 13 & 5 & 1 & & & 4 & & & & 1 & 6 & 16 \\
\hline Galicia & 75 & & 2 & 1 & 1 & 20 & 18 & 17 & 13 & 3 & 4 & 2 & 8 & 1 & & 2 & & 7 & 9 \\
\hline La Rioja & 32 & & & & & & 15 & 9 & 8 & 1 & 2 & & 2 & & & & & 8 & 3 \\
\hline C. Madrid & 35 & & & & & & 4 & 19 & 13 & 3 & & & 6 & & & & 1 & 6 & 12 \\
\hline Murcia & 42 & & & 1 & 2 & 11 & 18 & 13 & 7 & 2 & 2 & & 2 & & 1 & & 2 & 7 & 19 \\
\hline Navarra & 90 & & & & & & & & 16 & 16 & 1 & 3 & & 4 & & & & & \\
\hline País Vasco & 89 & 2 & 1 & 15 & 19 & 6 & 2 & & 21 & & 7 & & & & & & & 9 & \\
\hline C. Valenciana & 81 & & 3 & 1 & 3 & 14 & 21 & 14 & 19 & 4 & 5 & & 6 & & & 2 & & & 7 \\
\hline Total & 1060 & 7 & 19 & 32 & 79 & 154 & 253 & 204 & 179 & 54 & 38 & 6 & 43 & 20 & 6 & 16 & 22 & 73 & 169 \\
\hline
\end{tabular}

Source: Spanish Ministry of Regional Policyand own elaboration.

\footnotetext{
${ }^{7}$ Not necessarily at the same time, or in the same year, but when the Self-governing Statute was approved.
} 


\begin{tabular}{|c|c|c|c|c|c|c|c|c|c|c|c|c|c|c|c|}
\hline & 1996 & 1997 & 1998 & 1999 & 2000 & 2001 & 2002 & 2003 & 2004 & 2005 & 2006 & 2007 & 2008 & 2009 & 2010 \\
\hline Andalucía & 1 & 3 & & 3 & & & & 1 & 11 & 8 & 3 & 5 & 8 & & 1 \\
\hline Aragón & 1 & 2 & 6 & 3 & & 1 & 1 & & & 1 & 3 & 2 & 1 & & 5 \\
\hline P. Asturias & & & & 11 & 4 & 1 & & & & 6 & 1 & & 2 & & \\
\hline Baleares & 5 & 3 & 2 & 7 & & 5 & & & & 3 & 2 & 3 & & 1 & \\
\hline Canarias & 8 & & 7 & 2 & & 2 & & & 2 & & 3 & & & 1 & \\
\hline Cantabria & 25 & & 6 & 3 & & 2 & & & & & 9 & 2 & 3 & & \\
\hline Castilla-La Mancha & 5 & & 2 & 3 & & 2 & 2 & & & & 2 & & & & \\
\hline Castilla \& León & 7 & & 4 & 5 & 3 & 2 & 2 & 3 & & & 1 & & & & 3 \\
\hline Catalonia & 2 & 8 & 8 & 4 & 4 & 6 & 2 & 1 & 8 & 1 & 6 & 6 & 5 & 3 & 2 \\
\hline Extremadura & & 3 & & 5 & & 4 & & 2 & & & 2 & & & & \\
\hline Galicia & 11 & 6 & 5 & 8 & & & 1 & & 3 & & 2 & 3 & 7 & & \\
\hline La Rioja & 8 & 2 & 5 & & 6 & 2 & 1 & & & & 2 & & & & \\
\hline C. Madrid & 6 & 2 & 3 & 6 & 1 & 1 & 6 & 3 & 1 & & & & & & \\
\hline Murcia & & 2 & 2 & 5 & & 5 & 2 & 1 & & & & & 6 & & \\
\hline Navarra & & 10 & & 7 & 2 & 1 & & & & & & & & & \\
\hline País Vasco & 6 & & 2 & 1 & & & & & & & & & 2 & & \\
\hline C. Valenciana & 7 & 3 & 4 & 6 & 5 & & 1 & & 1 & 2 & 1 & & & 1 & \\
\hline Total & 92 & 44 & 56 & 79 & 25 & 34 & 18 & 11 & 26 & 21 & 37 & 21 & 33 & 6 & 11 \\
\hline
\end{tabular}

Source: Spanish Ministry of Regional Policy and own elaboration. 


\section{TABLES}

Table 1: Average Growth accounting decomposition of Spanish regions (SGC), period 1988-2004.

\begin{tabular}{lllll}
\hline SGC & TFP Growth rate & $\begin{array}{l}\text { GDP Growth Rate } \\
\text { (constant prices) }\end{array}$ & $\begin{array}{l}\text { Employment growth } \\
\text { rate }\end{array}$ & $\begin{array}{l}\text { Stock of Capital growth } \\
\text { rate (constant prices) }\end{array}$ \\
\hline Andalucía & $-0.58 \%$ & $3.23 \%$ & $2.92 \%$ & $4.49 \%$ \\
Aragón & $0.14 \%$ & $2.78 \%$ & $1.55 \%$ & $3.65 \%$ \\
P. Asturias & $0.36 \%$ & $1.92 \%$ & $0.25 \%$ & $2.70 \%$ \\
Baleares & $-1.40 \%$ & $3.08 \%$ & $3.17 \%$ & $5.34 \%$ \\
Canarias & $-1.18 \%$ & $3.27 \%$ & $4.00 \%$ & $4.56 \%$ \\
Cantabria & $0.37 \%$ & $3.06 \%$ & $1.67 \%$ & $3.66 \%$ \\
Castilla \& León & $0.07 \%$ & $2.22 \%$ & $0.88 \%$ & $3.16 \%$ \\
Castilla-La-Mancha & $-0.05 \%$ & $2.89 \%$ & $1.84 \%$ & $4.49 \%$ \\
Catalonia & $0.30 \%$ & $3.11 \%$ & $2.55 \%$ & $3.19 \%$ \\
Extremadura & $0.61 \%$ & $3.10 \%$ & $1.52 \%$ & $3.03 \%$ \\
Galicia & $0.43 \%$ & $2.48 \%$ & $0.29 \%$ & $3.59 \%$ \\
Madrid & $-0.27 \%$ & $3.10 \%$ & $3.19 \%$ & $3.91 \%$ \\
Murcia & $-0.69 \%$ & $3.24 \%$ & $2.93 \%$ & $4.75 \%$ \\
Navarra & $-0.73 \%$ & $2.78 \%$ & $2.19 \%$ & $4.94 \%$ \\
País Vasco & $-0.01 \%$ & $2.57 \%$ & $2.06 \%$ & $3.22 \%$ \\
Rioja & $0.66 \%$ & $3.72 \%$ & $1.44 \%$ & $4.27 \%$ \\
Valencia & $-0.25 \%$ & $3.03 \%$ & $2.64 \%$ & $3.74 \%$ \\
Average & $\mathbf{0 . 1 5 \%}$ & $\mathbf{2 . 9 2 \%}$ & $\mathbf{2 . 0 6 \%}$ & $\mathbf{3 . 9 2 \%}$ \\
\hline
\end{tabular}

This is the un-weighted average across all 17 SGC averages

Table 2: Descriptive statistics.

\begin{tabular}{llll}
\hline & Mean & Std & Observations \\
\hline Number of pages (stock) & 5,736 & 4,997 & 272 \\
Number of pages per power (stock) & 37.35 & 27.48 & 272 \\
Number of Norms (stock) & 2499 & 1952 & 272 \\
Number of Norms per power (stock) & 16.55 & 10.72 & 272 \\
Number of powers (stock) & 141.23 & 38.86 & 272 \\
Regional GDP & 2583984 & 2366836 & 272 \\
Regional expenditure ${ }^{\mathrm{ii}}$ & 27,500 & 30,334 & 272 \\
Population & $2,355,055$ & $2,034,009$ & 272 \\
TFP growth rate (\%) & -0.15 & 2.16 & 272 \\
Number of Large Commercial Outlets & 25.16 & 26.69 & $189^{\mathrm{iii}}$ \\
Area of Large Commercial Outlets & 437022 & 494774 & $189^{\mathrm{iii}}$ \\
Industrial designs & 123.02 & 164.29 & 323 \\
Patents & 140.34 & 184.30 & 323 \\
Trademarks & 3533.62 & 4744.85 & 323 \\
Industrial utilities & 184.58 & 251.80 & 323 \\
Trade names & 274.74 & 313.86 & 323 \\
\hline iillions of euros at constant prices of year 2000 & & \\
ii Thousands of euros at constant prices of year 1986 & & \\
iii These observations correspond to the period 1996-2006 & \\
IV Square meters &
\end{tabular}


Table 3.a. : Number of pages of regulation as a function of number of public employees and public expenditure: 1990-2006.

\begin{tabular}{|c|c|c|c|c|}
\hline & $\begin{array}{l}\text { Number of } \\
\text { pages of } \\
\text { regulation } \\
\text { (stock) }\end{array}$ & $\begin{array}{l}\text { Number of pages } \\
\text { over number of } \\
\text { powers (stock) }\end{array}$ & $\begin{array}{l}\text { Number of pages } \\
\text { of regulation } \\
\text { (stock) }\end{array}$ & $\begin{array}{l}\text { Number of pages } \\
\text { over number of } \\
\text { powers (stock) }\end{array}$ \\
\hline Constant & $\begin{array}{l}5.58^{* * * *} \\
(1.76)\end{array}$ & $\begin{array}{l}1.75 \\
(1.60)\end{array}$ & $\begin{array}{l}2.79 \\
(1.91)\end{array}$ & $\begin{array}{l}-0.34 \\
(1.74)\end{array}$ \\
\hline Public employees & $\begin{array}{l}0.09^{* * *} \\
(0.02)\end{array}$ & $\begin{array}{l}0.10^{* * *} \\
(0.01)\end{array}$ & - & - \\
\hline $\begin{array}{l}\% \text { Public employees in } \\
\text { population }\end{array}$ & - & - & $\begin{array}{l}3.12^{* * *} \\
(1.01)\end{array}$ & $\begin{array}{l}3.69^{* * *} \\
(0.93)\end{array}$ \\
\hline $\begin{array}{l}\text { Regional public } \\
\text { expenditure }\end{array}$ & $\begin{array}{l}0.15^{* * *} \\
(0.03)\end{array}$ & $\begin{array}{l}0.04 \\
(0.03)\end{array}$ & - & \\
\hline $\begin{array}{l}\% \text { Regional public } \\
\text { expenditure }\end{array}$ & - & - & $\begin{array}{l}1.86^{* * *} \\
(0.22)\end{array}$ & $\begin{array}{l}0.91^{* * *} \\
(0.20)\end{array}$ \\
\hline Population & $\begin{array}{l}0.10 \\
(0.11)\end{array}$ & $\begin{array}{l}0.08 \\
(0.10)\end{array}$ & $\begin{array}{l}0.17 \\
(0.13)\end{array}$ & $\begin{array}{l}0.18 \\
(0.12)\end{array}$ \\
\hline GDP & $\begin{array}{l}-0.00 \\
(0.01)\end{array}$ & $\begin{array}{l}-0.01 \\
(0.01)\end{array}$ & $\begin{array}{l}1.85^{* * *} \\
(0.22)\end{array}$ & $\begin{array}{l}0.90^{* * * *} \\
(0.20)\end{array}$ \\
\hline $\mathrm{R}^{2}$ & 0.99 & 0.99 & 0.99 & 0.99 \\
\hline Observations & 289 & 289 & 289 & 289 \\
\hline
\end{tabular}

All variables are in logs. All regressions include SGR and year dummies. Standard errors are reported among parenthesis. $(* * *)$ represent significance levels of $0.01,(* *)$ represents significance level of 0.05 while $(*)$ represents significance levels of 0.10 . 
Table 3.b: Number of norms of as a function of number of public employees and public expenditure: 1990-2006.

\begin{tabular}{|c|c|c|c|c|}
\hline & $\begin{array}{l}\text { Number of } \\
\text { norms (stock) }\end{array}$ & $\begin{array}{l}\text { Number of } \\
\text { norms (stock) }\end{array}$ & $\begin{array}{l}\text { Number of norms over } \\
\text { number of powers } \\
\text { (stock) }\end{array}$ & $\begin{array}{l}\text { Number of norms over } \\
\text { number of powers } \\
\text { (stock) }\end{array}$ \\
\hline Constant & $\begin{array}{l}8.31^{* * *} \\
(1.52)\end{array}$ & $\begin{array}{l}6.57^{* * *} \\
(1.62)\end{array}$ & $\begin{array}{l}3.43^{* * * *} \\
(1.50)\end{array}$ & $\begin{array}{l}4.48^{* * *} \\
(1.41)\end{array}$ \\
\hline Public employees & $\begin{array}{l}0.06^{* * *} \\
(0.01)\end{array}$ & - & - & $\begin{array}{l}0.07^{* * *} \\
(0.01)\end{array}$ \\
\hline $\begin{array}{l}\text { \%Public employees } \\
\text { in population }\end{array}$ & - & $\begin{array}{l}1.28 \\
(0.86)\end{array}$ & $\begin{array}{l}1.84^{* *} \\
(0.80)\end{array}$ & - \\
\hline $\begin{array}{l}\text { Regional public } \\
\text { expenditure }\end{array}$ & $\begin{array}{l}0.13^{* * *} \\
(0.02)\end{array}$ & - & - & $\begin{array}{l}0.01 \\
(0.02)\end{array}$ \\
\hline $\begin{array}{l}\text { \% Regional public } \\
\text { over GDP }\end{array}$ & - & $\begin{array}{l}1.52^{* * *} \\
(0.19)\end{array}$ & $\begin{array}{l}0.57^{* * *} \\
(0.17)\end{array}$ & - \\
\hline Population & $\begin{array}{l}-0.08 \\
(0.10)\end{array}$ & $\begin{array}{l}-0.07 \\
(0.11)\end{array}$ & $\begin{array}{l}-0.06 \\
(0.10)\end{array}$ & $\begin{array}{l}-0.10 \\
(0.09)\end{array}$ \\
\hline GDP & $\begin{array}{l}-0.01 \\
(0.01)\end{array}$ & $\begin{array}{l}1.50^{* * *} \\
(0.19)\end{array}$ & $\begin{array}{l}0.55^{* * *} \\
(0.18)\end{array}$ & $\begin{array}{l}-0.02^{* * *} \\
(0.00)\end{array}$ \\
\hline $\mathrm{R}^{2}$ & 0.99 & 0.56 & 0.99 & 0.99 \\
\hline Observations & 289 & 289 & 289 & 289 \\
\hline
\end{tabular}

All regressions include SGC and year dummies. All variables are in logs. Standard errors are reported among parenthesis. $(* * *)$ represent significance levels of $0.01,(* *)$ represents significance level of 0.05 while $(*)$ represents significance levels of 0.10

Table 4: Correlation coefficient of regulatory variables in 2003 with the index of restrictions in retail trade elaborated by the Spanish Competition authority in 2003.

\begin{tabular}{|c|c|c|c|c|}
\hline & $\begin{array}{l}\text { Number of pages } \\
\text { (stock) }\end{array}$ & $\begin{array}{l}\text { Number of pages } \\
\text { by number of } \\
\text { powers (stock) }\end{array}$ & $\begin{array}{l}\text { Number of norms } \\
\text { (stock) }\end{array}$ & $\begin{array}{l}\text { Number of norms } \\
\text { by number of } \\
\text { powers (stock) }\end{array}$ \\
\hline $\begin{array}{l}\text { Number of Legal } \\
\text { Barriers to Retail } \\
\text { Distribution } \\
\text { identified by } \\
\text { Spain competition } \\
\text { authorities }\end{array}$ & $0.55^{* *}$ & $0.53^{* *}$ & $0.52^{* *}$ & $0.42^{*}$ \\
\hline
\end{tabular}


Table 5.a. Number of large commercial outlets as a function of regulatory intensity: 1996-2006.

All regressions include SGC and year dummies. All variables are in logs. Standard errors are reported among parenthesis. Standard errors are adjusted by heteroskedasticy and autocorrelation for all.

\begin{tabular}{|c|c|c|c|c|}
\hline \multicolumn{5}{|l|}{$\begin{array}{l}\text { NUMBER OF } \\
\text { HYPERMARKETS }\end{array}$} \\
\hline Constant & $\begin{array}{l}28.96^{*} \\
(15.62)\end{array}$ & $\begin{array}{l}15.58 \\
(14.64)\end{array}$ & $\begin{array}{l}14.07 \\
(16.28)\end{array}$ & $\begin{array}{l}-1.22 \\
(15.27)\end{array}$ \\
\hline $\begin{array}{l}\text { Number of pages of } \\
\text { regulation (stock) }\end{array}$ & $\begin{array}{l}-1.74^{* * *} \\
(0.60)\end{array}$ & - & - & - \\
\hline $\begin{array}{l}\text { Average number of } \\
\text { pages per power } \\
\text { (stock) }\end{array}$ & - & $\begin{array}{l}-1.51^{* *} \\
(0.59)\end{array}$ & - & - \\
\hline $\begin{array}{l}\text { Number of Norms } \\
\text { (stock) }\end{array}$ & - & - & $\begin{array}{l}-2.44^{* * *} \\
(0.80)\end{array}$ & - \\
\hline $\begin{array}{l}\text { Number of Norms } \\
\text { per power (stock) }\end{array}$ & - & - & - & $\begin{array}{l}-1.98^{* * *} \\
(0.75)\end{array}$ \\
\hline $\begin{array}{l}\text { Regional Public } \\
\text { Expenditure }\end{array}$ & $\begin{array}{l}0.31 \\
(0.27)\end{array}$ & $\begin{array}{l}0.20 \\
(0.25)\end{array}$ & $\begin{array}{l}0.32 \\
(0.25)\end{array}$ & $\begin{array}{l}0.17 \\
(0.23)\end{array}$ \\
\hline Population & $\begin{array}{l}-0.94^{* *} \\
(0.44)\end{array}$ & $\begin{array}{l}-0.98^{* *} \\
(0.43)\end{array}$ & $\begin{array}{l}-0.97^{* *} \\
(0.48)\end{array}$ & $\begin{array}{l}-1.02^{* *} \\
(0.48)\end{array}$ \\
\hline GDP & $\begin{array}{l}0.20 \\
(0.98)\end{array}$ & $\begin{array}{l}0.52 \\
(1.01)\end{array}$ & $\begin{array}{l}1.48 \\
(1.01)\end{array}$ & $\begin{array}{l}1.66^{*} \\
(1.01)\end{array}$ \\
\hline $\mathrm{R}^{2}$ & 0.98 & 0.98 & 0.98 & 0.98 \\
\hline Observations & 187 & 187 & 187 & 187 \\
\hline
\end{tabular}

Observations belonging to the same SGC $(* * *)$ represent significance levels of $0.01,(* *)$ represents significance level of 0.05 while $(*)$ represents significance levels of 0.10 . 
Table 5.b. Area of large commercial outlets as a function of regulatory intensity: 1996-2006.

\begin{tabular}{|c|c|c|c|c|}
\hline \multicolumn{5}{|l|}{$\begin{array}{l}\text { AREA OF } \\
\text { LARGE } \\
\text { OUTLETS }\end{array}$} \\
\hline Constant & $\begin{array}{l}62.64^{* * *} \\
(19.33)\end{array}$ & $\begin{array}{l}49.14^{* * *} \\
(16.27)\end{array}$ & $\begin{array}{l}44.55^{*} \\
(23.62)\end{array}$ & $\begin{array}{l}31.78^{* *} \\
(21.20)\end{array}$ \\
\hline $\begin{array}{l}\text { Number of pages } \\
\text { of regulation } \\
\text { (stock) }\end{array}$ & $\begin{array}{l}-1.78^{* * *} \\
(0.62)\end{array}$ & - & - & - \\
\hline $\begin{array}{l}\text { Average number } \\
\text { of pages per } \\
\text { power (stock) }\end{array}$ & - & $\begin{array}{l}-1.57^{* *} \\
(0.62)\end{array}$ & 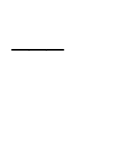 & 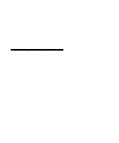 \\
\hline $\begin{array}{l}\text { Number of Norms } \\
\text { (stock) }\end{array}$ & - & - & $\begin{array}{l}-2.05^{*} \\
(1.17)\end{array}$ & - \\
\hline $\begin{array}{l}\text { Number of Norms } \\
\text { per power (stock) }\end{array}$ & - & 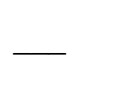 & - & $\begin{array}{l}-1.66^{*} \\
(1.04)\end{array}$ \\
\hline $\begin{array}{l}\text { Regional Public } \\
\text { expenditure }\end{array}$ & $\begin{array}{l}0.39 \\
(0.31)\end{array}$ & $\begin{array}{l}0.28 \\
(0.29)\end{array}$ & $\begin{array}{l}0.31 \\
(0.36)\end{array}$ & $\begin{array}{l}0.19 \\
(0.31)\end{array}$ \\
\hline Population & $\begin{array}{l}-0.05 \\
(0.61)\end{array}$ & $\begin{array}{l}-0.10 \\
(0.59)\end{array}$ & $\begin{array}{l}0.00 \\
(0.90)\end{array}$ & $\begin{array}{l}-0.04 \\
(0.87)\end{array}$ \\
\hline GDP & $\begin{array}{l}-2.21 \\
(1.26)\end{array}$ & $\begin{array}{l}-1.88^{*} \\
(1.19)\end{array}$ & $\begin{array}{l}-1.01 \\
(1.71)\end{array}$ & $\begin{array}{l}-0.85 \\
(1.60)\end{array}$ \\
\hline $\mathrm{R}^{2}$ & 0.97 & 0.97 & 0.97 & 0.97 \\
\hline Observations & 187 & 187 & 187 & 187 \\
\hline
\end{tabular}

Area is in square meters. All regressions include SGC and year dummies. All variables are in logs. Standard errors are reported among parenthesis. Standard errors are adjusted by heteroskedasticy and autocorrelation for al observations belonging to the same SGG $(* * *)$ represent significance levels of 0.01 , $(* *)$ represents significance level of 0.05 while $(*)$ represents significance levels of 0.10 . 
Table 6.a. Number of yearly patent applications as a function of regulatory intensity: 1990-2006

\begin{tabular}{|c|c|c|c|c|}
\hline \multicolumn{5}{|l|}{$\begin{array}{l}\text { NUMBER OF } \\
\text { PATENT } \\
\text { APPLICATIONS }\end{array}$} \\
\hline Constant & $\begin{array}{l}0.95 \\
(16.38)\end{array}$ & $\begin{array}{l}0.37 \\
(16.34)\end{array}$ & $\begin{array}{l}3.59 \\
(15.76)\end{array}$ & $\begin{array}{l}2.94 \\
(15.35)\end{array}$ \\
\hline $\begin{array}{l}\text { Number of pages } \\
\text { of regulation } \\
\text { (stock) }\end{array}$ & $\begin{array}{l}-0.57^{* * *} \\
(0.16)\end{array}$ & - & - & - \\
\hline $\begin{array}{l}\text { Average number } \\
\text { of pages per } \\
\text { power (stock) }\end{array}$ & - & $\begin{array}{l}-0.55^{* * *} \\
(0.23)\end{array}$ & - & - \\
\hline $\begin{array}{l}\text { Number of Norms } \\
\text { (stock) }\end{array}$ & - & - & $\begin{array}{l}-0.79^{* * *} \\
(0.25)\end{array}$ & - \\
\hline $\begin{array}{l}\text { Number of Norms } \\
\text { per power (stock) }\end{array}$ & - & - & - & $\begin{array}{l}-0.81^{* *} \\
(0.38)\end{array}$ \\
\hline $\begin{array}{l}\text { Regional Public } \\
\text { Expenditure }\end{array}$ & $\begin{array}{l}0.25^{* * *} \\
(0.10)\end{array}$ & $\begin{array}{l}0.19^{* * *} \\
(0.10)\end{array}$ & $\begin{array}{l}0.25^{* * *} \\
(0.09)\end{array}$ & $\begin{array}{l}0.17^{*} \\
(0.09)\end{array}$ \\
\hline Population & $\begin{array}{l}0.03 \\
(0.75)\end{array}$ & $\begin{array}{l}0.04 \\
(0.74)\end{array}$ & $\begin{array}{l}-0.33 \\
(0.70)\end{array}$ & $\begin{array}{l}-0.32 \\
(0.64)\end{array}$ \\
\hline GDP & $\begin{array}{l}0.48 \\
(0.76)\end{array}$ & $\begin{array}{l}0.35 \\
(0.74)\end{array}$ & $\begin{array}{l}0.75 \\
(0.64)\end{array}$ & $\begin{array}{l}0.58 \\
(0.66)\end{array}$ \\
\hline $\mathrm{R}^{2}$ & 0.96 & 0.96 & 0.96 & 0.96 \\
\hline Observations & 323 & 323 & 323 & 323 \\
\hline
\end{tabular}

Dependent variable is number of patents solicited. Standard errors are among parenthesis. Standard errors are adjusted by heteroskedasticy and autocorrelation for al observations belonging to the same SGC. All variables are in logs. All regressions include SGC dummies and year dummies. (***) represent significance levels of $0.01,(* *)$ represents significance level of 0.05 while $(*)$ represents significance levels of 0.10 . 
Table 6.b. Number of yearly utility model applications ("petty patents") as a function of the amount of regulation: 1990-2006.

\begin{tabular}{|c|c|c|c|c|}
\hline \multicolumn{5}{|l|}{$\begin{array}{l}\text { NUMBER OF } \\
\text { UTILITY MODEL } \\
\text { APPLICATIONS }\end{array}$} \\
\hline Constant & $\begin{array}{l}-0.91 \\
(17.32)\end{array}$ & $\begin{array}{l}-0.97 \\
(16.41)\end{array}$ & $\begin{array}{l}3.44 \\
(14.31)\end{array}$ & $\begin{array}{l}4.02 \\
(12.46)\end{array}$ \\
\hline $\begin{array}{l}\text { Number of pages } \\
\text { of regulation } \\
\text { (stock) }\end{array}$ & $\begin{array}{l}-0.42^{*} \\
(0.25)\end{array}$ & - & - & - \\
\hline $\begin{array}{l}\text { Average number } \\
\text { of pages per } \\
\text { power (stock) }\end{array}$ & - & $\begin{array}{l}-0.57^{* *} \\
(0.28)\end{array}$ & - & - \\
\hline $\begin{array}{l}\text { Number of Norms } \\
\text { (stock) }\end{array}$ & - & - & $\begin{array}{l}-1.01^{* * *} \\
(0.24)\end{array}$ & - \\
\hline $\begin{array}{l}\text { Number of Norms } \\
\text { per power (stock) }\end{array}$ & - & - & - & $\begin{array}{l}-1.33^{* * *} \\
(0.32)\end{array}$ \\
\hline $\begin{array}{l}\text { Regional Public } \\
\text { Expenditure }\end{array}$ & $\begin{array}{l}0.40^{* *} \\
(0.16)\end{array}$ & $\begin{array}{l}0.38^{* * *} \\
(0.16)\end{array}$ & $\begin{array}{l}0.48^{* * *} \\
(0.16)\end{array}$ & $\begin{array}{l}0.40^{* * *} \\
(0.14)\end{array}$ \\
\hline Population & $\begin{array}{l}-1.51 \\
(1.09)\end{array}$ & $\begin{array}{l}-1.46 \\
(1.10)\end{array}$ & $\begin{array}{l}-1.92^{* *} \\
(0.94)\end{array}$ & $\begin{array}{l}-1.99^{* *} \\
(0.86)\end{array}$ \\
\hline GDP & $\begin{array}{l}1.90^{* * *} \\
(1.18)\end{array}$ & $\begin{array}{l}1.78^{* * *} \\
(1.26)\end{array}$ & $\begin{array}{l}2.28^{* *} \\
(1.00)\end{array}$ & $\begin{array}{l}2.11^{* * *} \\
(1.02)\end{array}$ \\
\hline $\mathrm{R}^{2}$ & 0.96 & 0.96 & 0.96 & 0.97 \\
\hline Observations & 323 & 323 & 323 & 323 \\
\hline
\end{tabular}

Dependent variable is number of utilities solicited. Standard errors are among parenthesis. Standard errors are adjusted by heteroskedasticy and autocorrelation for al observations belonging to the same SGC. All variables are in logs. All regressions include SGC dummies and year dummies. (***) represent significance levels of $0.01,(* *)$ represents significance level of 0.05 while $(*)$ represents significance levels of 0.10 . 
Table 6.c.: Number of yearly trademark applications as a function of the amount of regulation: 1990-2006.

\begin{tabular}{|c|c|c|c|c|}
\hline \multicolumn{5}{|l|}{$\begin{array}{l}\text { NUMBER OF } \\
\text { TRADEMARK } \\
\text { APPLICATIONS }\end{array}$} \\
\hline Constant & $\begin{array}{l}-7.41 \\
(13.62)\end{array}$ & $\begin{array}{l}-7.65 \\
(13.61)\end{array}$ & $\begin{array}{l}-4.56 \\
(11.41)\end{array}$ & $\begin{array}{l}-5.02 \\
(11.42)\end{array}$ \\
\hline $\begin{array}{l}\text { Number of pages } \\
\text { of regulation } \\
\text { (stock) }\end{array}$ & $\begin{array}{l}-0.18 \\
(0.23)\end{array}$ & - & 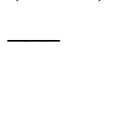 & 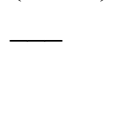 \\
\hline $\begin{array}{l}\text { Average number } \\
\text { of pages per } \\
\text { power (stock) }\end{array}$ & 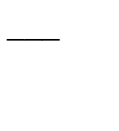 & $\begin{array}{l}-0.16 \\
(0.26)\end{array}$ & 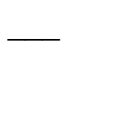 & - \\
\hline $\begin{array}{l}\text { Number of Norms } \\
\text { (stock) }\end{array}$ & - & - & $\begin{array}{l}-0.61^{* * *} \\
(0.21)\end{array}$ & - \\
\hline $\begin{array}{l}\text { Number of Norms } \\
\text { per power (stock) }\end{array}$ & - & - & - & $\begin{array}{l}-0.63^{* * *} \\
(0.27)\end{array}$ \\
\hline $\begin{array}{l}\text { Regional Public } \\
\text { Expenditure }\end{array}$ & $\begin{array}{l}0.20^{*} \\
(0.10)\end{array}$ & $\begin{array}{l}0.17^{*} \\
(0.10)\end{array}$ & $\begin{array}{l}0.26^{* *} \\
(0.10)\end{array}$ & $\begin{array}{l}0.20^{* *} \\
(0.09)\end{array}$ \\
\hline Population & $\begin{array}{l}-0.18 \\
(0.74)\end{array}$ & $\begin{array}{l}-0.17 \\
(0.74)\end{array}$ & $\begin{array}{l}-0.41 \\
(0.67)\end{array}$ & $\begin{array}{l}-0.40 \\
(0.67)\end{array}$ \\
\hline GDP & $\begin{array}{l}1.18 \\
(0.83)\end{array}$ & $\begin{array}{l}1.14 \\
(0.86)\end{array}$ & $\begin{array}{l}1.41^{* *} \\
(0.71)\end{array}$ & $\begin{array}{l}1.28^{*} \\
(0.73)\end{array}$ \\
\hline $\mathrm{R}^{2}$ & 0.98 & 0.98 & 0.98 & 0.98 \\
\hline Observations & 323 & 323 & 323 & 323 \\
\hline
\end{tabular}

Dependent variable is number of brands solicited. Standard errors are among parenthesis. Standard errors are adjusted by heteroskedasticy and autocorrelation for al observations belonging to the same SGC. All variables are in logs. All regressions include SGC dummies and year dummies. (***) represent significance levels of $0.01,(* *)$ represents significance level of 0.05 while $(*)$ represents significance levels of 0.10 . 
Table 6.d. Yearly Trade names applications as a function of the amount of regulation: 1990-2006.

\begin{tabular}{|c|c|c|c|c|}
\hline \multicolumn{5}{|l|}{$\begin{array}{l}\text { NUMBER OF } \\
\text { TRADE NAME } \\
\text { APPLICATIONS }\end{array}$} \\
\hline Constant & $\begin{array}{l}-1.49 \\
(10.69)\end{array}$ & $\begin{array}{l}-2.32 \\
(11.68)\end{array}$ & $\begin{array}{l}3.69 \\
(5.96)\end{array}$ & $\begin{array}{l}2.03 \\
(7.33)\end{array}$ \\
\hline $\begin{array}{l}\text { Number of pages } \\
\text { of regulation } \\
\text { (stock) }\end{array}$ & $\begin{array}{l}-0.53 \\
(0.35)\end{array}$ & - & - & - \\
\hline $\begin{array}{l}\text { Average number } \\
\text { of pages per } \\
\text { power (stock) }\end{array}$ & - & $\begin{array}{l}-0.38 \\
(0.37)\end{array}$ & - & - \\
\hline $\begin{array}{l}\text { Number of Norms } \\
\text { (stock) }\end{array}$ & - & - & $\begin{array}{l}-1.22^{* * *} \\
(0.33)\end{array}$ & - \\
\hline $\begin{array}{l}\text { Number of Norms } \\
\text { per power (stock) }\end{array}$ & - & - & - & $\begin{array}{l}-1.11^{* * *} \\
(0.40)\end{array}$ \\
\hline $\begin{array}{l}\text { Regional Public } \\
\text { Expenditure }\end{array}$ & $\begin{array}{l}0.29^{* * *} \\
(0.09)\end{array}$ & $\begin{array}{l}0.21^{* *} \\
(0.10)\end{array}$ & $\begin{array}{l}0.38^{* * *} \\
(0.09)\end{array}$ & $\begin{array}{l}0.24^{* *} \\
(0.10)\end{array}$ \\
\hline Population & $\begin{array}{l}-0.25 \\
(1.01)\end{array}$ & $\begin{array}{l}-0.27 \\
(1.00)\end{array}$ & $\begin{array}{l}-0.75 \\
(0.74)\end{array}$ & $\begin{array}{l}-0.69^{*} \\
(0.76)\end{array}$ \\
\hline GDP & $\begin{array}{l}0.88 \\
(1.13)\end{array}$ & $\begin{array}{l}0.79 \\
(1.16)\end{array}$ & $\begin{array}{l}1.34 \\
(0.87)\end{array}$ & $\begin{array}{l}1.04^{*} \\
(0.90)\end{array}$ \\
\hline $\mathrm{R}^{2}$ & 0.96 & 0.96 & 0.96 & 0.96 \\
\hline Observations & 323 & 323 & 323 & 323 \\
\hline
\end{tabular}

Dependent variable is number of industrial names solicited. Standard errors are among parenthesis. Standard errors are adjusted by heteroskedasticy and autocorrelation for al observations belonging to the same SGC. All variables are in logs. All regressions include SGC dummies and year dummies. (***) represent significance levels of $0.01,(* *)$ represents significance level of 0.05 while $(*)$ represents significance levels of 0.10 
Table 6.e. Yearly industrial design applications as a function of the amount of regulation: 19902006.

\begin{tabular}{|c|c|c|c|c|}
\hline \multicolumn{5}{|l|}{$\begin{array}{l}\text { NUMBER OF } \\
\text { INDUSTRIAL } \\
\text { DESIGN } \\
\text { APPLICATIONS }\end{array}$} \\
\hline Constant & $\begin{array}{l}-16.67 \\
(32.86)\end{array}$ & $\begin{array}{l}-15.97 \\
(31.51)\end{array}$ & $\begin{array}{l}-12.84 \\
(30.01)\end{array}$ & $\begin{array}{l}-11.07 \\
(27.55)\end{array}$ \\
\hline $\begin{array}{l}\text { Number of pages } \\
\text { of regulation } \\
\text { (stock) }\end{array}$ & $\begin{array}{l}0.11 \\
(0.57)\end{array}$ & - & - & - \\
\hline $\begin{array}{l}\text { Average number } \\
\text { of pages per } \\
\text { power } \\
\text { (stock) }\end{array}$ & - & $\begin{array}{l}-0.17 \\
(0.53)\end{array}$ & - & - \\
\hline $\begin{array}{l}\text { Number of Norms } \\
\text { (stock) }\end{array}$ & - & - & $\begin{array}{l}-0.62 \\
(0.57)\end{array}$ & - \\
\hline $\begin{array}{l}\text { Number of Norms } \\
\text { per power } \\
\text { (stock) }\end{array}$ & - & - & - & $\begin{array}{l}-1.13^{* * *} \\
(0.69)\end{array}$ \\
\hline $\begin{array}{l}\text { Regional Public } \\
\text { Expenditure }\end{array}$ & $\begin{array}{l}0.25 \\
(0.21)\end{array}$ & $\begin{array}{l}0.31 \\
(0.20)\end{array}$ & $\begin{array}{l}0.39^{* *} \\
(0.20)\end{array}$ & $\begin{array}{l}0.37 \\
(0.19)\end{array}$ \\
\hline Population & $\begin{array}{l}-0.43 \\
(1.34)\end{array}$ & $\begin{array}{l}-0.37 \\
(1.30)\end{array}$ & $\begin{array}{l}-0.61 \\
(1.27)\end{array}$ & $\begin{array}{l}-0.75 \\
(1.18)\end{array}$ \\
\hline GDP & $\begin{array}{l}1.61^{*} \\
(1.37)\end{array}$ & $\begin{array}{l}1.59 \\
(1.40)\end{array}$ & $\begin{array}{l}1.86^{*} \\
(1.10)\end{array}$ & $\begin{array}{l}1.81^{*} \\
(1.00)\end{array}$ \\
\hline $\mathrm{R}^{2}$ & 0.92 & 0.92 & 0.92 & 0.92 \\
\hline Observations & 323 & 323 & 323 & 323 \\
\hline
\end{tabular}

Dependent variable is number of industrial designs solicited. Standard errors are among parenthesis. Standard errors are adjusted by heteroskedasticy and autocorrelation for al observations belonging to the same SGC. All variables are in logs. All regressions include SGC dummies and year dummies. $(* * *)$ represent significance levels of $0.01,(* *)$ represents significance level of 0.05 while $\left({ }^{*}\right)$ represents significance levels of 0.10 .

Table 7: Average increase in annual Total Factor Productivity before the period under study (19801987) and during the period of study (1988-2004).

Average annual increase in Total Factor Productivity

\begin{tabular}{lll}
\hline & $\begin{array}{l}\text { Regions with high increase in } \\
\text { regulation in 1988-2004 }\end{array}$ & $\begin{array}{l}\text { Regions with low increase in } \\
\text { regulation in 1988-2004 }\end{array}$ \\
\hline $1980-1987$ & $0.13 \%$ & $-0.19 \%$ \\
$1988-2003$ & $-0.03 \%$ & $0.03 \%$ \\
\hline
\end{tabular}

SGC with high/low increase in regulation are those with an increase in the number of pages per power assumed in the period 1988-2003 higher/lower than the median. 
Table 8: Total Factor Productivity growth rate as a function of regulatory intensity: 1988-2004.

\begin{tabular}{|c|c|c|c|c|}
\hline \multicolumn{5}{|l|}{ TFP growth rate } \\
\hline Constant & $\begin{array}{l}-2.31^{* * *} \\
(0.53)\end{array}$ & $\begin{array}{l}-2.34^{* * *} \\
(0.55)\end{array}$ & $\begin{array}{l}-1.98^{* * *} \\
(0.51)\end{array}$ & $\begin{array}{l}-2.08^{* * *} \\
(0.46)\end{array}$ \\
\hline $\begin{array}{l}\text { Number of pages } \\
\text { of regulation } \\
\text { (stock) }\end{array}$ & $\begin{array}{l}-0.02^{*} \\
(0.01)\end{array}$ & - & - & - \\
\hline $\begin{array}{l}\text { Average number } \\
\text { of pages per } \\
\text { power } \\
\text { (stock) }\end{array}$ & - & $\begin{array}{l}-0.01 \\
(0.01)\end{array}$ & - & 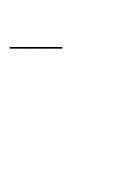 \\
\hline $\begin{array}{l}\text { Number of Norms } \\
\text { (stock) }\end{array}$ & - & - & $\begin{array}{l}-0.05^{* *} \\
(0.02)\end{array}$ & 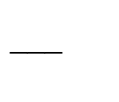 \\
\hline $\begin{array}{l}\text { Number of Norms } \\
\text { per power (stock) }\end{array}$ & - & 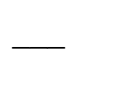 & 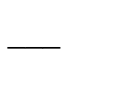 & $\begin{array}{l}-0.04^{* * *} \\
(0.02)\end{array}$ \\
\hline $\begin{array}{l}\text { Regional Public } \\
\text { Expenditure }\end{array}$ & $\begin{array}{l}0.01 \\
(0.01)\end{array}$ & $\begin{array}{l}0.00 \\
(0.01)\end{array}$ & $\begin{array}{l}0.01^{*} \\
(0.01)\end{array}$ & $\begin{array}{l}0.00 \\
(0.01)\end{array}$ \\
\hline Population & $\begin{array}{l}-0.06^{* *} \\
(0.04)\end{array}$ & $\begin{array}{l}-0.06^{* *} \\
(0.03)\end{array}$ & $\begin{array}{l}-0.09^{* * *} \\
(0.03)\end{array}$ & $\begin{array}{l}-0.08^{* * *} \\
(0.02)\end{array}$ \\
\hline GDP & $\begin{array}{l}0.22^{* * * *} \\
(0.04)\end{array}$ & $\begin{array}{l}0.21^{* * *} \\
(0.04)\end{array}$ & $\begin{array}{l}0.24^{* * *} \\
(0.03)\end{array}$ & $\begin{array}{l}0.22^{* * *} \\
(0.03)\end{array}$ \\
\hline $\mathrm{R}^{2}$ & 0.41 & 0.40 & 0.43 & 0.42 \\
\hline Observations & 272 & 272 & 272 & 272 \\
\hline
\end{tabular}

Dependent variable is TFP growth rate. Robust Standard errors are among parenthesis. All variables are in logs. All regressions include SGC dummies and year dummies. $(* * *)$ represent significance levels of $0.01,(* *)$ represents significance level of 0.05 while $(*)$ represents significance levels of 0.10 
Table 9. Different measures of productivity, innovation and competition as a function of lagged variables of regulatory intensity.

\begin{tabular}{|c|c|c|c|c|c|}
\hline & $\begin{array}{l}\text { TFP } \\
\text { regression }\end{array}$ & $\begin{array}{l}\text { Number of } \\
\text { hypermarkets } \\
\text { regression }\end{array}$ & $\begin{array}{l}\text { Square meter of } \\
\text { hypermarkets }\end{array}$ & $\begin{array}{l}\text { Number } \\
\text { of Brands }\end{array}$ & $\begin{array}{l}\text { Number } \\
\text { of } \\
\text { patents }\end{array}$ \\
\hline $\begin{array}{l}\text { Lagged } \\
\text { number of } \\
\text { pages (stock) }\end{array}$ & $\begin{array}{l}-0.01 \\
(0.01)\end{array}$ & $\begin{array}{l}-1.73^{* * *} \\
(0.27)\end{array}$ & $\begin{array}{l}-1.74^{* * *} \\
(0.38)\end{array}$ & $\begin{array}{l}-0.13 \\
(0.11)\end{array}$ & $\begin{array}{l}-0.42^{* *} \\
(0.16)\end{array}$ \\
\hline $\begin{array}{l}\text { Lagged } \\
\text { number of } \\
\text { pages per } \\
\text { power (stock) }\end{array}$ & $\begin{array}{l}-0.00 \\
(0.01)\end{array}$ & $\begin{array}{l}-1.36^{* * *} \\
(0.24)\end{array}$ & $\begin{array}{l}-1.51^{* * *} \\
(0.33)\end{array}$ & $\begin{array}{l}-0.10 \\
(0.11)\end{array}$ & $\begin{array}{l}-0.40^{* *} \\
(0.17)\end{array}$ \\
\hline $\begin{array}{l}\text { Lagged } \\
\text { Number of } \\
\text { Norms (stock) }\end{array}$ & $\begin{array}{l}-0.05^{* * *} \\
(0.01)\end{array}$ & $\begin{array}{l}-2.28^{* * *} \\
(0.28)\end{array}$ & $\begin{array}{l}-1.81^{* * *} \\
(0.43)\end{array}$ & $\begin{array}{l}-0.64^{* * *} \\
(0.12)\end{array}$ & $\begin{array}{l}-0.75^{* * *} \\
(0.19)\end{array}$ \\
\hline $\begin{array}{l}\text { Lagged } \\
\text { Number of } \\
\text { Norms per } \\
\text { power } \\
\text { (stock) }\end{array}$ & $\begin{array}{l}-0.05^{* * *} \\
(0.01)\end{array}$ & $\begin{array}{l}-1.83^{* * *} \\
(0.26)\end{array}$ & $\begin{array}{l}-1.65^{* * *} \\
(0.38)\end{array}$ & $\begin{array}{l}-0.66^{* * *} \\
(0.13)\end{array}$ & $\begin{array}{l}-0.78^{* * *} \\
(0.20)\end{array}$ \\
\hline
\end{tabular}

Standard errors are among parenthesis. All variables are in logs. All regressions include SGC dummies, year dummies and controls of GDP, Population and Local Public Expenditure. (***) represent significance levels of $0.01,(* *)$ represents significance level of 0.05 while $(*)$ represents significance levels of 0.10 . 
Table 10: Total Factor Productivity growth rate as a function of regulatory intensity: 1988-2004. Instrumental Variable estimation.

\begin{tabular}{lll}
\hline TFP growth rate & & \\
\hline Constant & $-2.47^{* * *}$ & $-1.97^{* * *}$ \\
& $(0.77)$ & $(0.73)$ \\
$\begin{array}{l}\text { Number of pages } \\
\text { of regulation }\end{array}$ & $-0.08^{* *}$ & - \\
(stock) & $(0.04)$ & \\
& & - \\
$\begin{array}{l}\text { Average number } \\
\text { of pages per } \\
\text { power (stock) }\end{array}$ & - & \\
& & $-0.08^{* * *}$ \\
Number of Norms & - & $(0.03)$ \\
(stock) & & \\
& & \\
Number of Norms & - & \\
per power (stock) & & 0.01 \\
& $0.02^{*}$ & $(0.01)$ \\
Regional Public & $(0.01)$ & $-0.10^{* *}$ \\
Expenditure & & $(0.04)$ \\
& -0.03 & $0.25^{* * *}$ \\
Population & $(0.05)$ & $(0.05)$ \\
GDP & $0.21^{* * *}$ & 0.43 \\
& $(0.05)$ & 272 \\
$\mathrm{R}^{2}$ & 0.38 & \\
Observations & 272 & \\
\hline
\end{tabular}

Dependent variable is TFP growth rate. The Table shows the result of the second stage of a 2SIV estimation in which the instrument we use in the first stage is the number of powers assigned to a given SGC at a given point in time. All variables are in logs. Standard errors are among parenthesis. All regressions include SGC dummies and year dummies. (***) represent significance levels of $0.01,(* *)$ represents significance level of 0.05 while $(*)$ represents significance levels of 0.10 .

Table 11: Number of business establishments as a function of regulatory intensity.

\begin{tabular}{|l|l|}
\hline & OLS \\
\hline Number of pages (logs) & -0.1476 \\
& $(0.0927)$ \\
\hline Average number of pages per & -0.1936 \\
power (logs) & $(0.1225)$ \\
\hline Number of Norms (logs) & -0.1287 \\
& $(0.1683)$ \\
\hline Average Number of Norms per & -0.1603 \\
power (logs) & $(0.1761)$ \\
\hline
\end{tabular}

Coefficients on the distinct measures of regulatory intensity in four distinct regression with 29,240 observations in which the dependent variable is log of the number of business establishments and the controls are 289 industry dummies, 17 regional dummies, six year dummies (the regression includes values from 1999 to 2006) and log of population, log of GDP and log of public expenditure. Standard errors are clustered by region. 
Table 12: Size bins reported in dataset DIRCE.

\begin{tabular}{ll}
\hline $\begin{array}{l}\text { Size bin of establishments reported by the } \\
\text { DIRCE }\end{array}$ & Assumed average employee per establishment \\
\hline No employees & 0 \\
1 or 2 employees & 1 \\
3 to 5 employees & 3 \\
6 to 9 employees & 6 \\
10 to 19 employees & 10 \\
20 to 49 employees & 20 \\
50 to 99 employees & 50 \\
100 to 199 employees & 100 \\
200 to 499 employees & 200 \\
500 or more employees & 2857 \\
\hline
\end{tabular}

Table 13: Percentage of activity accounted by large companies as a function of regulation intensity.

\begin{tabular}{|l|l|l|}
\hline & $\begin{array}{l}\text { Proportion of } \\
\text { employment } \\
\text { accounted by } \\
\text { companies with } \\
\text { 500 or more } \\
\text { employees }\end{array}$ & $\begin{array}{l}\text { Proportion of } \\
\text { employment } \\
\text { accounted by } \\
\text { companies with } \\
\text { 200 or more } \\
\text { employees }\end{array}$ \\
\hline Number of pages & $-0.10^{* *}$ & $-0.08^{* *}$ \\
& $(0.04)$ & $(0.04)$ \\
\hline Average Number & $-0.10^{* *}$ & $-0.10^{* *}$ \\
of pages & $(0.06)$ & $(0.04)$ \\
\hline Number of Norms & $-0.13^{* *}$ & -0.06 \\
& $(0.05)$ & $(0.04)$ \\
\hline Average Number & $-0.11^{* *}$ & $-0.08^{*}$ \\
of Norms & $(0.06)$ & $(0.05)$ \\
\hline Observations & 1766 & 1766 \\
\hline
\end{tabular}

All regressions include regional dummies, industry dummies and year dummies. Standard errors are clustered by regions. It includes regional observations of 12 industries from 1999 to 2006.

Table 14: Estimation of Rossi-Hansberg-Wright (2007) regressions.

\begin{tabular}{llll}
\hline Estimation of $\beta$ & $\begin{array}{l}\text { Pooling regression 1999- } \\
\text { 2006 with year dummies }\end{array}$ & $\begin{array}{l}\text { Cross section regression } \\
\text { year 1999 }\end{array}$ & $\begin{array}{l}\text { Cross section } \\
\text { regression year 2006 }\end{array}$ \\
\hline Number of pages & $-0.0106^{* * *}$ & $-0.0490^{* * *}$ & $-0.0372^{* *}$ \\
& $(0.0031)$ & $(0.0101)^{* * *}$ & $(0.0144)^{* *}$ \\
Average Number of & $-0.0087^{* * *}$ & $-0.0821^{* *}$ & $-0.0470^{* *}$ \\
pages & $(0.0030)$ & $(0.0129)$ & $(0.0189)^{* *}$ \\
Number of Norms & $-0.0124^{* * *}$ & $-0.0584^{* * *}$ & $-0.0405^{* * *}$ \\
& $(0.004)$ & $(0.0106)^{* * *}$ & $(0.0146)$ \\
Average Number of & $-0.0096^{* *}$ & $-0.0834^{* *}$ & -0.0480 \\
Norms & $(0.0042)$ & $(0.0129)$ & $(0.0184)$ \\
Number of observations & 12502 & 1550 & 1576 \\
\hline
\end{tabular}

Estimation of $\beta$ in the equation

$$
\log P_{i j}=a_{i j}+b_{i j} \log n_{i j}+\gamma\left(\log n_{i j}\right)^{2}+\beta * \text { RegIntensity }_{i}\left(\log n_{i j}\right)^{2}
$$

Where $P_{i j}$ represents probability in industry $\mathrm{j}$ in region $\mathrm{i}$ of having an establishment with more than $n_{i j}$ employees; and $a_{i j}$ and $b_{i j}$ are industry-regional parameter using a weighted least squares regression in which the weights are the inverse of the number of establishments in each region-industry for the last two columns. For the first column we use clustered standard errors by region. 


\section{GRAPHS}

Graph 1: 1980-2003 evolution of TFP growth rate in Spanish SGC according to the increase in regulatory intensity in 1988-2003.

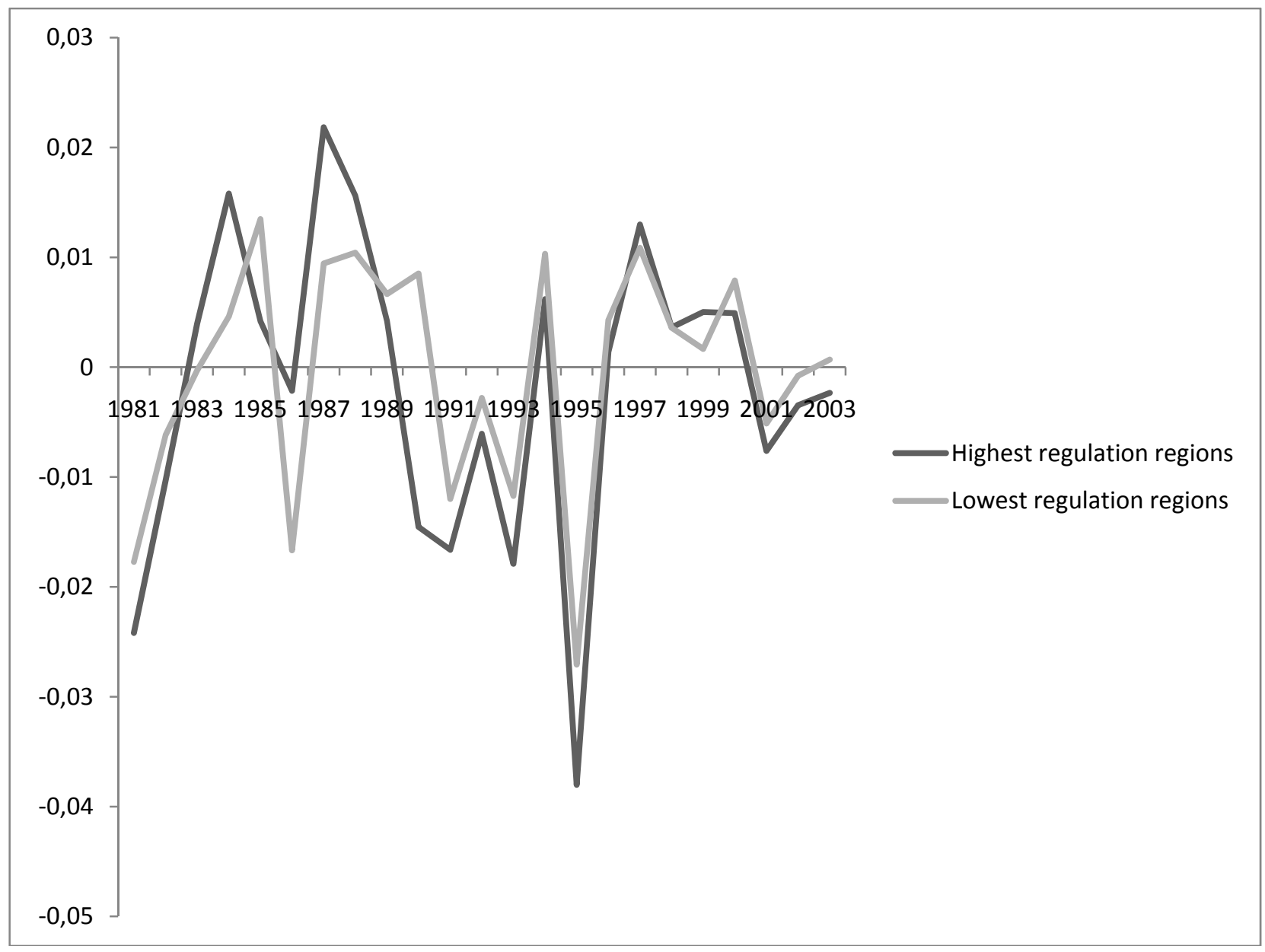


Graph 2: Increase in percentage of employees working for business establishments with 200 or more employees as a function of the \% increase in the number of regional (SGC) norms (1999-2006).

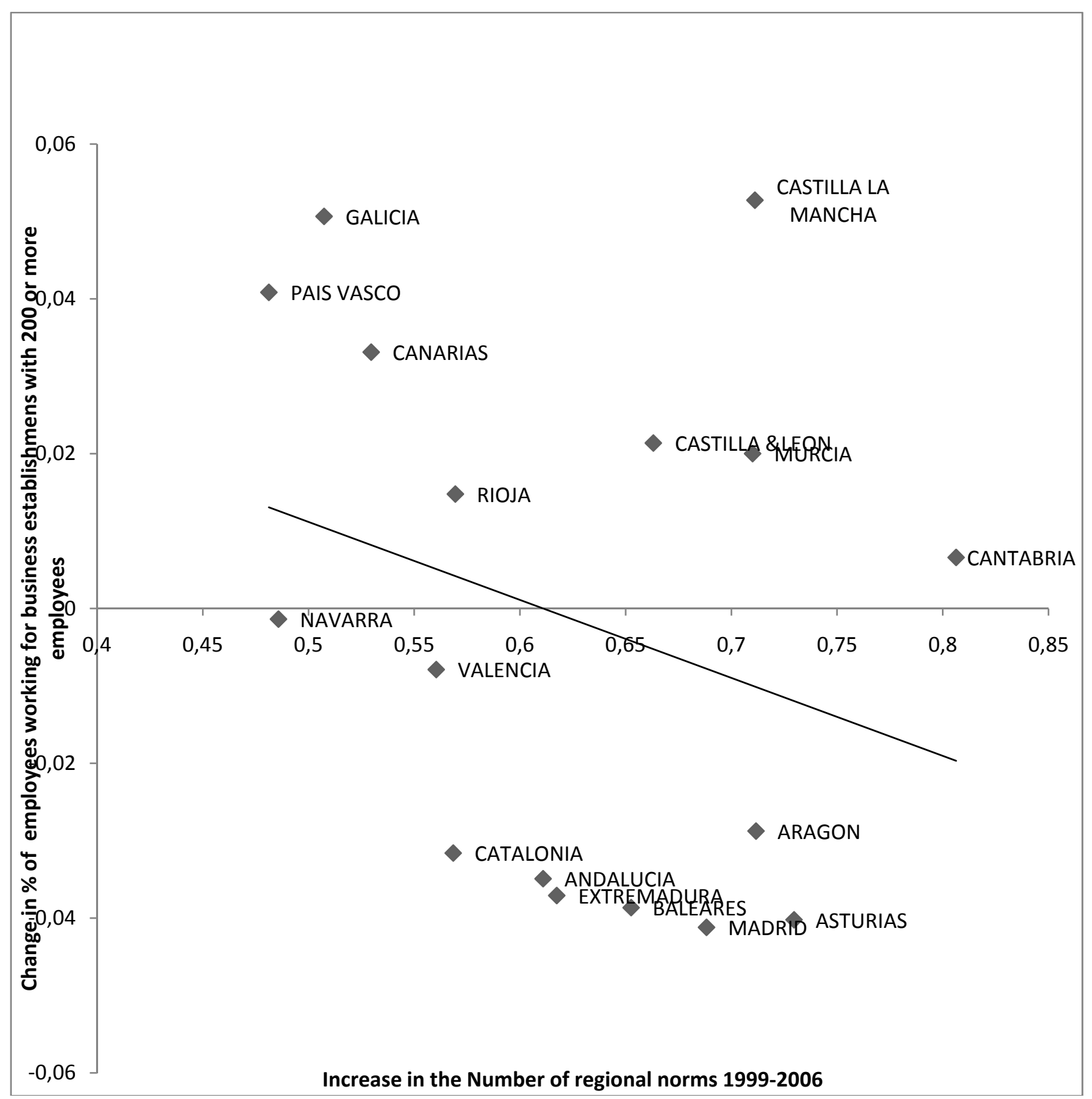


Graph 3.a. Changes in the business establishment-size distribution in SGCs with the largest increase in the number of norms in 1999-2006.

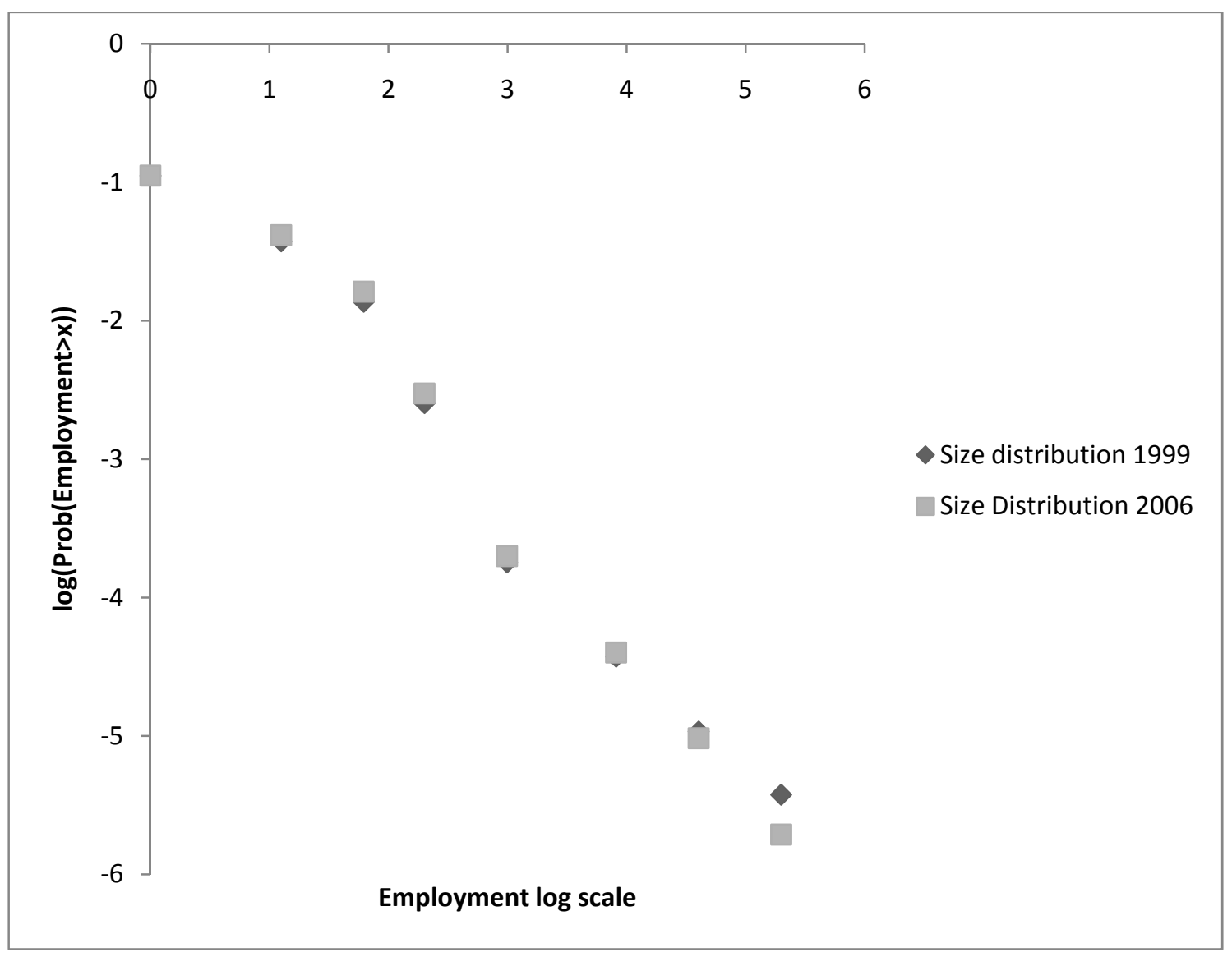


Graph 3.b. Changes in the business establishment-size distribution in SGCs with the lowest increase in the number of norms in 1999-2006.

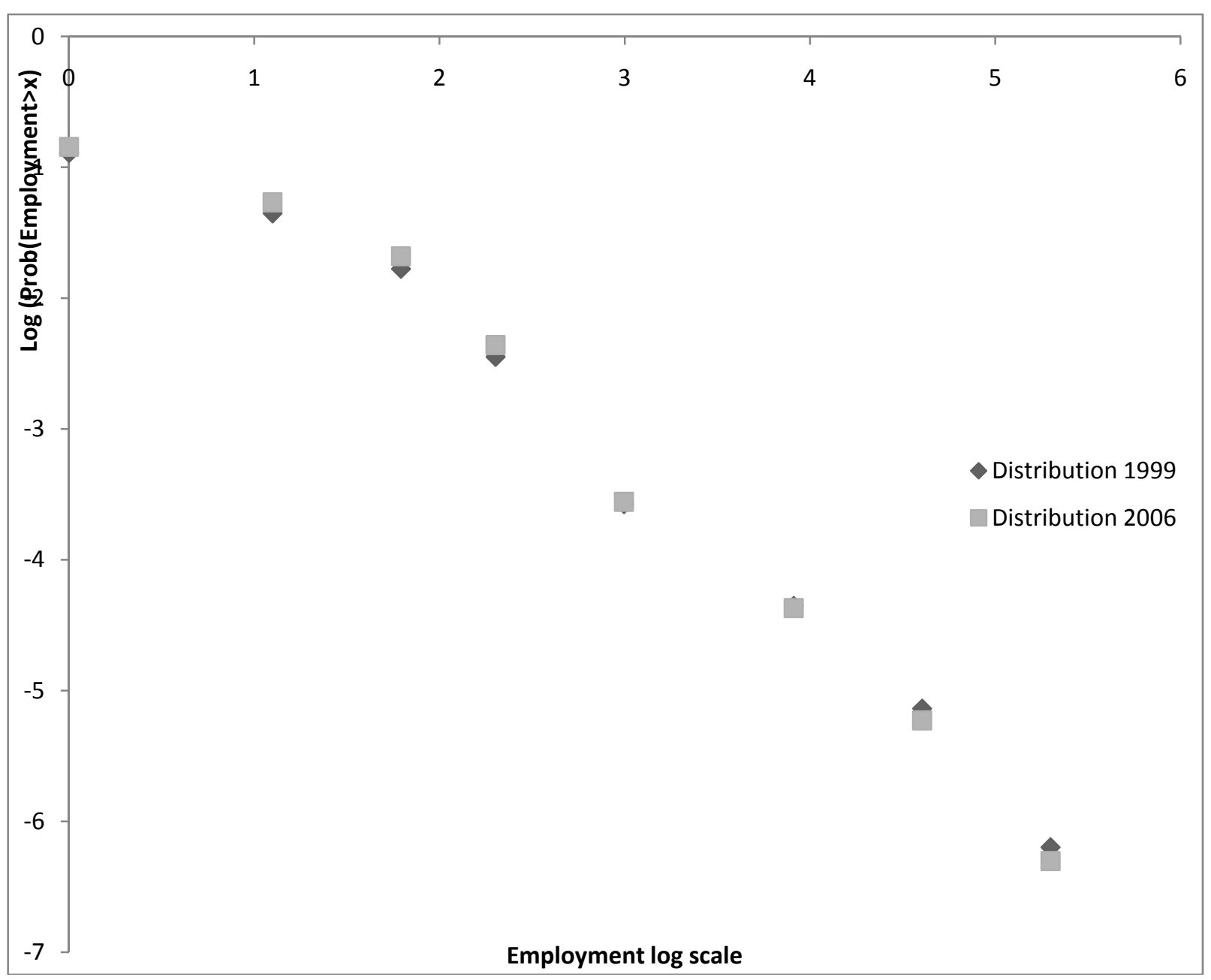

